\title{
The isotopic composition of water vapour and precipitation in Ivittuut, southern Greenland
}

\author{
J.-L. Bonne ${ }^{1}$, V. Masson-Delmotte ${ }^{1}$, O. Cattani ${ }^{1}$, M. Delmotte ${ }^{1}$, C. Risi ${ }^{3}$, H. Sodemann ${ }^{2}$, and H. C. Steen-Larsen ${ }^{1}$ \\ ${ }^{1}$ Laboratoire des Sciences du Climat et de l'Environnement, UMR8212, Gif sur Yvette, France \\ ${ }^{2}$ Institute for Atmospheric and Climate Science, ETH Zurich, Zurich, Switzerland \\ ${ }^{3}$ Laboratoire de Météorologie Dynamique, Paris, France
}

Correspondence to: J.-L. Bonne (jean-louis.bonne@lsce.ipsl.fr)

Received: 14 October 2013 - Published in Atmos. Chem. Phys. Discuss.: 21 November 2013

Revised: 11 March 2014 - Accepted: 20 March 2014 - Published: 7 May 2014

Abstract. Since September 2011, a wavelength-scanned cavity ring-down spectroscopy analyser has been remotely operated in Ivittuut, southern Greenland, providing the first record of surface water vapour isotopic composition based on continuous measurements in South Greenland and the first record including the winter season in Greenland. The comparison of vapour data with measurements of precipitation isotopic composition suggest an equilibrium between surface vapour and precipitation.

$\delta^{18} \mathrm{O}$ and deuterium excess are generally anti-correlated and show important seasonal variations, with respective amplitudes of $\sim 10$ and $\sim 20 \%$, as well as large synoptic variations. The data depict small summer diurnal variations. At the seasonal scale, $\delta^{18} \mathrm{O}$ has a minimum in NovemberDecember and a maximum in June-July, while deuterium excess has a minimum in May-June and a maximum in November. The approach of low-pressure systems towards South Greenland leads to $\delta^{18} \mathrm{O}$ increase (typically $+5 \%$ ) and deuterium excess decrease (typically $-15 \%$ o).

Seasonal and synoptic variations coincide with shifts in the moisture sources, estimated using a quantitative moisture source diagnostic based on a Lagrangian back-trajectory model. The atmospheric general circulation model LMDZiso correctly captures the seasonal and synoptic variability of $\delta^{18} \mathrm{O}$, but does not capture the observed magnitude of deuterium excess variability.

Covariations of water vapour isotopic composition with local and moisture source meteorological parameters have been evaluated. $\delta^{18} \mathrm{O}$ is strongly correlated with the logarithm of local surface humidity, consistent with Rayleigh distillation processes, and with local surface air temperature, associated with a slope of $\sim 0.4 \% 0^{\circ} \mathrm{C}^{-1}$. Deuterium excess correlates with local surface relative humidity as well as surface relative humidity from the dominant moisture source area located in the North Atlantic, south of Greenland and Iceland.

\section{Introduction}

Stable water isotopes (designating the water stable isotopologues $\mathrm{H}_{2} \mathrm{O}, \mathrm{H}_{2}^{18} \mathrm{O}$ and $\mathrm{HDO}$ ) in atmospheric waters are widely used as tracers of the hydrological cycle (Jouzel, 2003). In Greenland ice cores, stable water isotopes have been used to quantify past changes in climate and in the water cycle. We briefly summarize the key findings and questions arising from Greenland ice core studies, as they motivate a better understanding of the processes at play from presentday studies.

A brief description of stable water isotopes basics is given here. The isotopic composition of water is expressed in $\%$ units, using $\delta$ notation, defined as a deviation of the sample isotopic ratio $R$ compared to a standard isotopic ratio $R_{\text {VSMOW: }}$

$\delta=1000 \times\left(R / R_{\mathrm{VSMOW}}-1\right)$.

In this work, we focus on $\delta^{18} \mathrm{O}$ and $\delta \mathrm{D}$ isotopic compositions (corresponding to $\mathrm{H}_{2}^{18} \mathrm{O}$ and $\mathrm{HDO}$ isotopologues) of water vapour and precipitation, based on in situ continuous observations. Hereafter, precipitation and vapour observations are respectively noted with the subscripts $\mathrm{p}$ and $\mathrm{v}$. 
Since stable water isotopes have different saturation vapour pressure and diffusivity in the air, fractionation processes occur during phase changes (such as evaporation or condensation). They produce strong temporal and spatial variations of atmospheric water vapour and precipitation isotopic composition. These variations are driven by continuous removal of heavier isotopes during poleward transport, sometimes called atmospheric distillation, and are affected by changes in moisture sources and transport histories. As changes in temperature strongly control this distillation and the isotopic composition of precipitation at mid and high latitudes, this forms the basis for past temperature reconstructions using records of precipitation isotopic composition in archives such as ice cores (Jouzel, 2003). In addition to equilibrium fractionation, kinetic processes take place for instance during evaporation or condensation on ice crystals. The second-order parameter deuterium-excess (hereafter denoted $d$, where $d=\delta \mathrm{D}-8 \times \delta^{18} \mathrm{O}$ ) has been introduced to identify deviations from the average relationship between $\delta^{18} \mathrm{O}$ and $\delta \mathrm{D}$ in meteoric waters (presenting a mean slope of 8) and highlight kinetic effects (Dansgaard, 1964; Craig and Gordon, 1965; Merlivat and Jouzel, 1979).

The oldest climate record extracted from Greenland ice core now reaches $128.5 \mathrm{kyr}$ in NEEM (NEEM Community Members, 2013). High-resolution records have documented the seasonal cycle of surface snow isotopic composition (Johnsen, 1977), and seasonal changes during the past millennia (Vinther et al., 2010). Initially, the quantitative interpretation of Greenland ice core stable water isotopes records in terms of temperature was based on an isotope-temperature relationship. This relationship was deduced from modern spatial surface snow and precipitation isotopic data and surface air or firn temperatures (Dansgaard, 1964; Sjolte et al., 2011; Johnsen et al., 1992). The comparison of past temperatures inferred from borehole temperature profiles and from gas fractionation (Severinghaus and Brook, 1999; DahlJensen et al., 1998; Cuffey et al., 1992; Vinther et al., 2010; Masson-Delmotte et al., 2011) has demonstrated that the isotope-temperature relationship varies through time, possibly due to changes in precipitation seasonality (Krinner et al., 1997; Krinner and Werner, 2003) and intermittency (Persson et al., 2011), and in moisture origin (Sime et al., 2013). Statistical and back-trajectory analyses have depicted a strong imprint of the North Atlantic Oscillation (NAO) on winter and annual ice core isotopic signals, associated with large shifts of the mean moisture sources, consistent with its imprint on instrumental temperature records (Vinther et al., 2010; Casado et al., 2012; Sodemann et al., 2008a; Sodemann et al., 2008b). Rapid strong shifts in $d$ have been documented during abrupt events (Steffensen et al., 2008; Thomas et al., 2009), together with significant changes at the orbital scale, possibly related to major changes in moisture sources (Masson-Delmotte et al., 2005; Jouzel et al., 2007). The combination of different ice core records has recently made it possible to investigate the regional patterns of past changes in precipitation stable water isotopes and climate (Steen-Larsen et al., 2011; Guillevic et al., 2012). All these studies indicate that the quantitative understanding of Greenland ice core records requires improved comprehension of the different processes controlling Greenland surface snow isotopic composition. This calls for a continuous monitoring of water vapour, precipitation and surface snow isotopic composition, in order to decipher, at the atmospheric process scale, the drivers of transport, deposition and post-deposition effects.

Under the auspices of the GNIP/IAEA (Global Network of Isotopes in Precipitation/International Atomic Energy Agency), Greenland coastal precipitation has been sampled at different locations and analysed for water isotopic composition, at the monthly scale, during specific time intervals (Rozanski et al., 1993; Sjolte et al., 2011), limiting the analyses to seasonal timescales. The isotopic composition of Greenland water vapour has remained for long undocumented, due to the difficulty of trapping water vapour without fractionation and the manpower requested for manual cold trap sampling (Jacob and Sonntag, 1991).

In recent years, new types of infrared laser spectrometers have been developed, allowing high-frequency in situ measurements of water vapour isotopic composition. If an appropriate measurement and calibration protocol is applied (Tremoy et al., 2011; Aemisegger et al., 2012; Steen-Larsen et al., 2013), these instruments reach a precision close to classical instruments based on isotope-ratio mass spectrometry. In the Arctic region, data have been reported for Siberia, showing large-magnitude synoptic events (Gribanov et al., 2013). A recent monitoring effort has been implemented at the NEEM Greenland ice core drilling site. During summer, precipitation, surface water vapour and surface snow were sampled for isotopic measurements (Steen-Larsen et al., 2011, 2013, 2014a), in order to better understand the postdeposition processes affecting the ice core signals. The data have evidenced a diurnal variability, attributed to snow-air water vapour interactions. The surface snow and the snowfall isotopic composition being consistent with water vapour isotopic composition assuming equilibrium, this could indicate that a large water exchange could take place between the snowpack and the lower atmosphere. These NEEM data also show synoptic events with high $d$ values, a potential signature of Arctic air masses (Steen-Larsen et al., 2013). A water vapour cold trap sampling campaign has also been conducted above the Arctic Ocean onboard a research vessel (Kurita, 2011). Combined with Siberian precipitation data, the data suggest a specific fingerprint of moisture formed at the sea-ice margin, in autumn, where dry air can produce a large kinetic fractionation and produce high $d$ values. So far, however, no study has been dedicated to the water vapour at coastal and southern Greenland locations and during the winter season over all Greenland, which would make it possible to investigate the isotopic fingerprints of North Atlantic moisture sources. 
Recent publications have focused on the interpretation of $d$ in water vapour and precipitation in terms of moisture source oceanic conditions. Observations conducted above or close to the Mediterranean (Pfahl and Wernli, 2008), the Southern Ocean (Uemura et al., 2008) and the eastern North Atlantic Ocean (Benetti et al., 2014) have consistently demonstrated a dominant control of surface relative humidity on surface vapour $d$, with slopes varying between -0.4 and $-0.6 \%$ \% $\%^{-1}$ ). This marine source signal appears to be preserved along transportation when it is dominated by distillation processes, but appears to be mitigated by convective processes in tropical areas such as the Bay of Bengal during monsoon (Midhun et al., 2013). Risi et al. (2008) has demonstrated the strong influence of convection on the isotopic composition of water vapour and precipitation in the tropics. Jouzel et al. (2013) attempted to estimate the information concerning oceanic sources in water vapour $d$ signal for different types of locations.

Our study is focused on the atmospheric monitoring station of Ivittuut, southern Greenland, situated close to Grønnedal, where precipitation isotopic composition was measured by GNIP/IAEA in the 1960s and 1970s (see Supplement Sect. A). This site is situated almost at sea level, and is therefore complementary of the monitoring conducted at NEEM during summer, at an elevation of $2500 \mathrm{~m}$ a.s.l. (Steen-Larsen et al., 2013). In September 2011, we implemented an in situ continuous analyser of water vapour isotopic composition at this station. Our observation period covers events of strong heat waves in summer 2012, associated with strong advection of heat and humidity from further south (Fettweis et al., 2013; Bennartz et al., 2013; Nghiem et al., 2012; Neff et al., 2013).

This paper is organized into five sections. Section 2 describes material and methods. Section 3 is dedicated to the description of the water vapour and precipitation isotopic data and their relationship with local climate and changes in moisture transport, investigated using a Lagrangian moisture source identification (Sodemann et al., 2008b). Section 4 compares Ivittuut observations to the LMDZiso nudged isotope-enabled atmospheric general circulation model (AGCM) (Risi et al., 2010a). AGCM simulations make it possible to explore the spatial representativeness of station data, but also to assess whether the model correctly resolves the meteorological drivers of the local water vapour isotopic composition. Conclusions and perspectives are given in Sect. 5.

\section{Methods and data}

In this section, we focus on the methodologies implemented for obtaining the different data sets. We first present the sampling site in Sect. 2.1, then the observations, and then the atmospheric modelling framework. Section 2.2 presents the acquisition of meteorological observations. Section 2.3

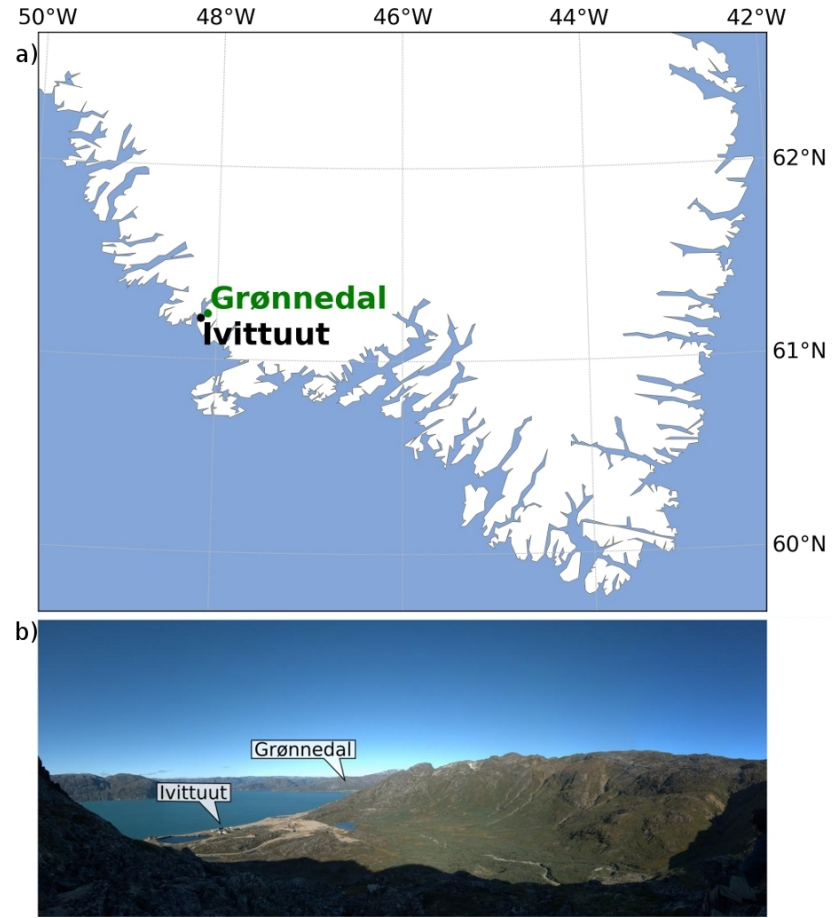

Fig. 1. Southern Greenland map (a). Arsuk Fjord in autumn 2011, seen from the southwest, showing Ivittuut and Grønnedal (b).

describes the monitoring of precipitation isotopic composition and the associated calculation of water vapour isotopic composition. Section 2.4 is dedicated to the water vapour isotopic composition monitoring and presents the instrumental protocol and the data treatment chain. The difficulties encountered during data acquisition and the modifications implemented to our methodology to overcome these problems are presented in Sect. 2.5. The final data quality estimation is also presented here. Sections 2.7 and 2.8 respectively present the large-scale atmospheric models used for data interpretation: the FLEXPART Lagrangian dispersion model, and the LMDZiso AGCM equipped with stable water isotopes.

\subsection{Sampling site}

The atmospheric monitoring station of Ivittuut, southern Greenland $\left(61.21^{\circ} \mathrm{N}, 48.17^{\circ} \mathrm{W}\right.$, altitude $30 \mathrm{~m}$ a.s.l.), depicted in Fig. 1, was established in Autumn 2007 for the monitoring of $\mathrm{CO}_{2}$ and $\mathrm{O}_{2} / \mathrm{N}_{2}$ atmospheric mixing ratios, giving access to atmospheric potential oxygen (Stephens et al., 1998). The site was chosen in order to study the role of the North Atlantic Ocean as a carbon sink, as part of the EU CarboOcean project.

This Greenlandic coastal site is located $100 \mathrm{~m}$ from the Arsuk Fjord, at approximately $5 \mathrm{~km}$ east of the open ocean and $10 \mathrm{~km}$ west of the ice sheet. Arctic vegetation, mainly bushes and grasslands, is present in the valley, surrounded by mountains. A few buildings from an abandoned cryolite 
mine have been renovated in Ivittuut, located $5 \mathrm{~km}$ from the Grønnedal village and Danish Navy military base (Fig. 1). A meteorological station was set up in Autumn 2007, measuring temperature, pressure, relative humidity, wind speed and direction. In September 2011, new instruments were installed in order to monitor the $\mathrm{CH}_{4}$ mixing ratio as well as water vapour isotopic composition (see next sections). All instruments are located in a heated building. Electricity is provided by the Ivittuut power station, situated about $100 \mathrm{~m}$ from the station. Basic maintenance is operated by technicians from the Danish Navy. Heavy maintenance is conducted once a year by LSCE (Laboratoire des Sciences du Climat et de l'Environnement, Saclay, France).

Measurements from the atmospheric monitoring instruments are automatically transferred to LSCE. Online access allows daily monitoring and control of the instruments.

\subsection{Meteorological data}

High-frequency (around $1 \mathrm{~Hz}$ ) meteorological measurements have been obtained at Ivittuut station since September 2007. Temperature and relative humidity are measured by a Vaisala humidity and temperature Probe HMP155 (situated $1.8 \mathrm{~m}$ above ground), wind direction and speed by a Young 05603B sensor (situated on the roof top, about $3.5 \mathrm{~m}$ above ground), and pressure by a Druck RPT 410 sensor $(1.8 \mathrm{~m}$ above ground). A failure of the sensor acquisition card led to several gaps in the acquisition of the data during the observation period (see Sect. 3).

Complementary historical meteorological information is available from the measurements at Grønnedal with the framework of GNIP/IAEA, from 1961 to 1974 (available at http://nucleus.iaea.org/CIR/CIR/GNIPIHIS.html, 2013).

\subsection{Precipitation stable water isotopes data and equilibrium vapour isotopic calculations}

Monthly historical isotope observations of precipitation in Grønnedal are available through the GNIP/IAEA network from 1961 to 1974 inclusive.

In September 2011, two rain gauges were installed, one at Ivittuut and one at Grønnedal. Water is sampled manually at an approximately weekly frequency for the Grønnedal rain gauge and an approximately bi-weekly frequency for Ivittuut rain gauge. Water samples are stored in glass bottles closed with plastic caps and packed in cellophane film after sampling. They are then shipped and analysed at LSCE using a mass spectrometer or Picarro liquid water isotope analyser, with accuracies of $0.7 \%$ or $\delta \mathrm{D}_{\mathrm{p}}$ and $0.025 \%$ o for $\delta^{18} \mathrm{O}_{\mathrm{p}}$ (resulting in $0.9 \%$ ofor $d_{\mathrm{p}}$ ). The type of precipitation (liquid or snow) is recorded, depending of the water phase in the collector at the time of sampling, as well as the precipitation amount. Both rain gauges sustained damage caused by winter storms, leading to gaps in the precipitation data. The most complete data set is the one from Grønnedal, ranging from
October 2011 to November 2012, with a gap from June to August 2012.

Some samples were discarded as their isotopic compositions were suspected of having evolved in the collector between the time of the precipitation event and of the sampling: either they were frozen in the collector or their isotopic composition deviated from the meteoric water line, leading to the suspicion of evaporation. For the latter case, we discarded samples for which the isotopic $\delta \mathrm{D} / \delta^{18} \mathrm{O}$ ratio was above a threshold of 9.5 . We finally obtained six validated samples in Ivittuut from 15 September 2012 to 1 March 2012 and 39 validated samples in Grønnedal from 16 September 2011 to 5 November 2012.

Theoretical water vapour isotopic composition is calculated at equilibrium with precipitation, using the fractionation coefficient at equilibrium $\alpha$, for $\delta^{18} \mathrm{O}$ and $\delta \mathrm{D}$, from Majoube (1971a, b) and Merlivat and Nief (1967). For each precipitation sample, with an isotopic ratio denoted $R_{\mathrm{P}}$, we use this fractionation coefficient to calculate a theoretical isotopic ratio of vapour denoted $R \mathrm{~V}$, which is given by $R_{\mathrm{V}}=R_{\mathrm{P}} / \alpha$. Fractionation coefficients between either solid and vapour or liquid and vapour were used. As no direct observation of the physical phase of the condensates in the clouds is available, we made the simple assumption that the condensates were formed in the same phase as found in the collector. We used fractionation coefficients between liquid and vapour for liquid samples, and between solid and vapour phases for snow samples. Because the exact time and dates of the precipitation events were not known, or the altitude of the condensation of water vapour in the cloud, the temperatures used to calculate the $\alpha$ coefficients were approximated. The temperature used was the surface temperature observed at the station, averaged between two precipitation samplings. The precision of each theoretical water vapour isotopic composition at equilibrium was calculated using a Monte Carlo simulation, taking into account the variation of temperature during the sampling period (impacting on $\alpha$ coefficients) and the precision of precipitation isotopic composition measurements.

\subsection{Water vapour isotope monitoring}

A Picarro brand model L2120- $i$ wavelength-scanned cavity ring-down spectroscopy (WS-CRDS) analyser, hereafter Picarro, was installed in September 2011 at Ivittuut station, in the basement of the building to ensure a better temperature stability in the room. The experimental design and data treatment procedure are similar to those described in Gribanov et al. (2013). Ambient air is sampled through a $10 \mathrm{~m}$ long and 3/8 inch diameter O'Brien analytical True Tube EPS (inox $316 \mathrm{~L}$ chromium electropolished), a material chosen to limit wall effects between the inner tube and the water vapour in the air sample. Air is sampled about $5 \mathrm{~m}$ a.g.l. The sampling line is temperature autoregulated (Wheatstone bridge) and protected against rain, snow and insects by a hard cover 
Table 1. Theoretical values and humidity correction coefficients for "GREEN" and "EPB" standards, for $\delta \mathrm{D}$ and $\delta^{18} \mathrm{O}$. The $a, b$ and $c$ are the coefficients used in Eq. (2).

\begin{tabular}{|c|c|c|c|c|}
\hline \multirow{2}{*}{$\begin{array}{l}\text { Name } \\
\text { Isotope }\end{array}$} & \multicolumn{2}{|c|}{ GREEN } & \multicolumn{2}{|c|}{$\mathrm{EPB}$} \\
\hline & $\delta^{18} \mathrm{O}$ & $\delta \mathrm{D}$ & $\delta^{18} \mathrm{O}$ & $\delta \mathrm{D}$ \\
\hline Value $(\% o)$ & $-32.99 \pm 0.05$ & $-256.0 \pm 0.5$ & $-6.12 \pm 0.05$ & $-43.2 \pm 0.5$ \\
\hline$a$ & $188.3 \times 10^{4}$ & $159.6 \times 10^{5}$ & $117.2 \times 10^{3}$ & $467.2 \times 10^{2}$ \\
\hline$b$ & 444.0 & -13948.0 & -618.0 & -29562.9 \\
\hline$c$ & -29.1 & -234.6 & -4.2 & -34.7 \\
\hline
\end{tabular}

Table 2. Summary of experimental difficulties and evolutions which occurred to the Picarro instrument between 21 September 2011 and 31 May 2013.

\begin{tabular}{|c|c|c|c|c|}
\hline Beginning & End & Failure description & Solution applied & Effects \\
\hline 12 Nov 2011 & 6 Feb 2012 & $\begin{array}{l}\text { Ambient air sampling head destroyed } \\
\text { by wind }\end{array}$ & Head replaced, inlet line dried & $\begin{array}{l}\text { No ambient air mea- } \\
\text { surement }\end{array}$ \\
\hline 6 Feb 2012 & 1 Apr 2012 & Calibration system water saturation & Calibration system dried & No calibration \\
\hline Jul 2012 & 21 Feb 2013 & $\begin{array}{l}\text { Leaks on one calibration system SDM } \\
\text { syringe }\end{array}$ & $\begin{array}{l}\text { Calibrations with one standard alter- } \\
\text { nated every week ( } 9 \text { Nov } 2012 \text { to } \\
21 \text { Feb 2013) }\end{array}$ & $\begin{array}{l}\text { Unstable standard } \\
\text { measurements }\end{array}$ \\
\hline 1 Sep 2012 & 9 Nov 2012 & $\begin{array}{l}\text { Simultaneous leaks on both SDM sy- } \\
\text { ringes }\end{array}$ & Syringe cleaned & No calibration \\
\hline 29 Mar 2013 & 12 Apr 2013 & Leaks on calibration air drying system & DRIERITE replaced & No calibration \\
\hline Date & & System evolution & \multicolumn{2}{|l|}{ Effects } \\
\hline 25 Oct 2012 & \multicolumn{2}{|c|}{$\begin{array}{l}\text { Manual dry air flow regulator replaced by fixed flow } \\
\text { restrictor }\end{array}$} & \multicolumn{2}{|l|}{ Calibrations more stable } \\
\hline $21 \mathrm{Feb} 2013$ & \multicolumn{2}{|c|}{ SDM ceramic syringes replaced by glass syringes } & \multicolumn{2}{|c|}{ No more leaks on SDM syringes, calibrations more stable } \\
\hline
\end{tabular}

and a net. An automatic calibration system using the Picarro brand standard delivery module (SDM) is used to measure the isotopic composition of vaporized water standards, calibrated on the VSMOW scale by accurate laboratory mass spectrometer measurements. Two water standards, EPB and GREEN (Table 1), are injected by SDM in the Picarro brand vaporizer and vaporized at $140^{\circ} \mathrm{C}$, then mixed with dry air (room air desiccated with DRIERITE changed every 1 or 2 months depending of the ambient air humidity) and measured by the analyser. Adjusting the liquid water and/or dry air flow levels makes it possible to measure the water standards at different humidity levels. Several adjustments during our observation period, summarized in Table 2, led to more stable calibrations.

The influence of the humidity level on laser-spectroscopic stable isotope measurements has been identified in several recent calibration studies, and appears to be dependent on the instrument and the calibration system (Aemisegger et al., 2012; Tremoy et al., 2011; Steen-Larsen et al., 2013). To assess the humidity-isotope response function of our instrument, both water standards were measured at different humidity levels from 1000 to 17000 ppmv (Fig. 2). This test was performed on field in October 2012 and is assumed to remain stable. The response functions were fitted for each isotope and each standard, with the best fit obtained using the following equations giving $\delta X$ (either $\delta^{18} \mathrm{O}$ or $\delta \mathrm{D}$ ) as a function of humidity $\mathrm{H}_{2} \mathrm{O}_{\text {ppmv }}$ :

$$
\delta X=a+\frac{b}{\mathrm{H}_{2} \mathrm{O}_{\mathrm{ppmv}}}+\frac{c}{\left(\mathrm{H}_{2} \mathrm{O}_{\mathrm{ppmv}}\right)^{2}} .
$$

Table 1 shows the coefficients of the humidity correction function obtained for each standard and each isotope.

A classical measurement sequence consists of 6 to $9 \mathrm{~h}$ of ambient air measurements, followed by successive measurements of each water standard for the calibration of the system. The instrument is thus frequently calibrated at a given humidity level to correct data from a potential instrumental drift. However, a leak on one of the SDM syringes (from July 2012 to 21 February 2013, Table 2) constrained us to measure only one standard during a calibration sequence. For each injection of water standard (lasting $30 \mathrm{~min}$ ), the isotopic measurements are integrated over the last $20 \mathrm{~min}$ to account for the stabilization time of the system.

Figure 3 illustrates the humidity levels and the isotopic compositions of all calibrations during our observation period, averaged over this $20 \mathrm{~min}$ period, for the GREEN 

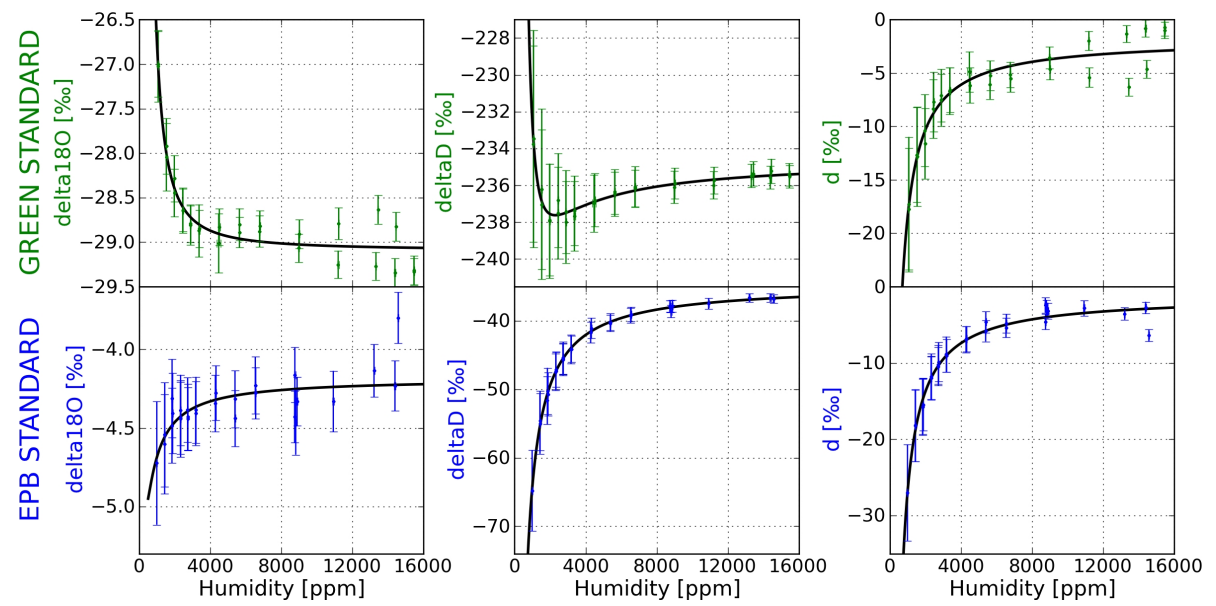

Fig. 2. PICARRO measurements of two reference waters (GREEN and EBP standards) as a function of the humidity mixing ratio, controlled through injection flow of liquid water. The different response functions for $\delta^{18} \mathrm{O}$ and $\delta \mathrm{D}$ at low humidity levels (below $2000 \mathrm{ppmv}$ ) are likely an artifact of residual humidity in the dry air (dried by DRIERITE).

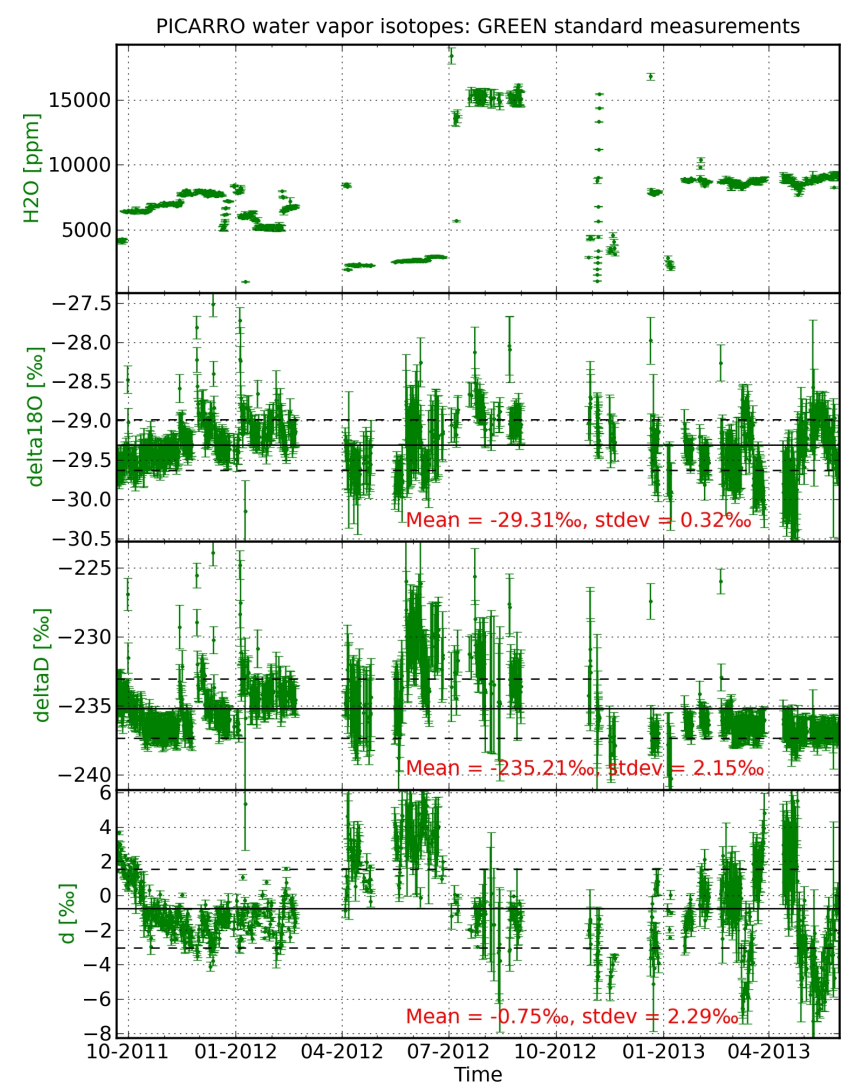

Fig. 3. Successive measurements of GREEN standard for PICARRO calibration: averaged values on the last $20 \mathrm{~min}$ of each measurement sequence. Isotopic values are all corrected by Eq. (2) at an arbitrary humidity mixing ratio of $10000 \mathrm{ppmv}$. Top to bottom panels: humidity mixing ratio (ppmv), $\delta^{18} \mathrm{O}(\%), \delta \mathrm{D}(\% \circ)$ and $d(\% \circ)$. standard. The humidity level at which calibrations were performed was modified several times. Initially, the aim was to make standard measurements at the same humidity level as ambient air, but the technical difficulties inherent in the frequent adjusting of humidity level required us to rather use a constant humidity level. Figure 3 shows the raw measured humidity levels, whereas the isotopic composition values are corrected using Eq. (2) and reported for a constant humidity level of 10000 ppmv. As seen in Fig. 3, there is no highfrequency variability in water standard measurements. The typical variability timescale is above 1 week.

Instabilities can occur if air bubbles perturb the liquid water delivery system of the SDM, or if the dry air flow is not stable. In order to validate calibration sequences, an automatic criterion was applied to select stable standard measurements. This criterion is based on the standard deviations of the measurements of humidity, $\delta^{18} \mathrm{O}$ and $\delta \mathrm{D}$, and depends on the mean humidity level (it was noticed that instabilities were in general higher for higher average humidity levels). Standard measurements are not taken into account if one of the standard deviations of $\delta^{18} \mathrm{O}, \delta \mathrm{D}$ or humidity level exceeds respectively $1 \% \circ, 6 \%$, and $\sigma_{\text {humidity,max }}$ (expressed in ppmv). $\sigma_{\text {humidity,max }}$ is empirically defined as

$\sigma_{\text {humidity, } \max }=0.043 \times\langle$ humidity $\rangle+57$,

where 〈humidity is the average humidity level during all the injection time.

Every single ambient air measurement is independently calibrated following a series of steps. After each water standard measurement, no ambient air measurement is taken into account for $5.5 \mathrm{~min}$ (to avoid memory effects from the previous standard). For ambient air calibration, we search the two closest validated measurements of each water standard (one standard measurement prior and one standard measurement after the ambient air measurement). At least one of both 
standard measurements must be closer than 1.5 days from the ambient air measurement, otherwise this calibration is not used and the ambient air data are invalidated. The isotopic values of these standard measurements are first corrected using the humidity response function (Eq. 2) to the ambient air humidity level. Then, these two corrected standard measurements are interpolated at the time of the ambient air measurement. A linear regression curve is computed against their theoretical values, for each isotope. This regression is finally applied to calibrate the ambient air value.

\subsection{Data gaps and data quality control}

The instrument installation was completed on 21 September 2011. All experimental difficulties which occurred up to 31 May 2013 are summarized in Table 2. Several problems interrupted the water vapour isotopic monitoring and the performance of the calibration system, sometimes leading to data gaps over several months due to delays in shipping material to the station and to the low frequency of maintenance missions. In this 618 days period, we have validated water vapour isotopic measurements during 351 days (an overall performance of about $57 \%$ in a semi-autonomous run).

The main issue identified here is a difference in the humidity response function for low humidity levels $(<2000 \mathrm{ppmv})$ obtained for the two water standards (Fig. 2). This is probably due to residual humidity in the dry air injected (through DRIERITE). This contrasts with other studies based on dry air from tank cylinders (Aemisegger et al., 2012). The impact of this process is detected for humidity $<4000 \mathrm{ppmv}$ and is significant for humidity $<2000$ ppmv. This calls for a cautious interpretation of ambient air data obtained at humidity $<2000$ ppmv, which are only encountered episodically. During our observation period, $3 \%$ of hourly humidity measurements are below $2000 \mathrm{ppmv}$ when isotopic measurements are available (distributed over 53 days).

Calibrations were conducted at low humidity levels $(<3000$ ppmv) in the period April-June 2012 (Fig. 3). During this period, the standard deviation of each measurement is larger than for medium humidity levels (500010000 ppmv). The humidity correction introduced a small but significant effect on $d$ measurements, as evidenced by systematic positive anomalies of the standard measurements (around 3 to $4 \%$ o). This may result in an effect on $d$ values which might be artificially too low during this period.

The repetition of measurements of both calibration water standards is the only test we could perform to estimate the instrument stability. The standard deviations of all water standards measurements are similar for both standards and are presented in Fig. 3 for GREEN standard. They are around $0.3 \%$ for $\delta^{18} \mathrm{O}$ and $2.2 \%$ for $\delta \mathrm{D}$, leading to a standard deviation of about $2.3 \%$ for $d$.

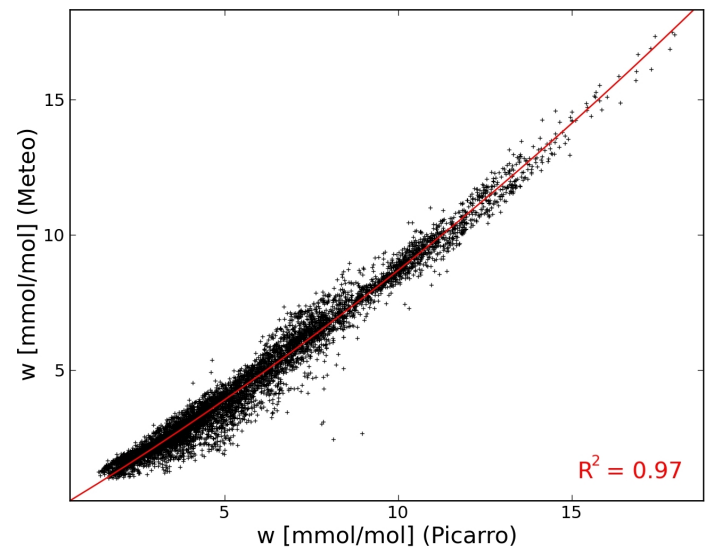

Fig. 4. Black crosses: hourly averaged observations at Ivittuut station from 21 September 2011 to 31 May 2013, Picarro vs. meteorological sensor mixing ratio $\left(\mathrm{mmol}_{\mathrm{water}} \mathrm{mol}_{\text {dry air }}^{-1}\right)$. Red curve: second-order polynomial regression (Eq. 4).

\subsection{Independent humidity measurements}

The Picarro humidity mixing ratio values are compared to those derived from the meteorological sensor relative humidity and temperature measurements. Hereafter, the humidity measurements are reported in water vapour molar mixing ratio (in $\mathrm{mmol}_{\text {water }} \mathrm{mol}_{\text {dry air }}^{-1}$ ). As seen in Fig. 4, hourly averaged data from those two independent sensors over the full data sets from 21 September 2011 to 31 May 2013 are fitted by the following second-order polynomial function with a high determination coefficient $\left(R^{2}=0.97\right)$ :

$y=0.013 x^{2}+0.77 x-0.25$,

where $y$ gives meteorological sensor mixing ratio and $x$ the Picarro mixing ratio.

In the $1-18 \mathrm{mmol} \mathrm{mol}^{-1}$ range, our comparison shows a nonlinear relationship between the Picarro instrument and the meteorological sensor. Earlier studies have reported different results when comparing Picarro measurements with independent humidity observations. Aemisegger et al. (2012) showed a linear response of the analysers using a dew point generator to control humidity level in a $4-31 \mathrm{mmol} \mathrm{mol}^{-1}$ range. Tremoy et al. (2011) showed a nonlinear response of the analyser compared to humidity based on meteorological sensor temperature and relative humidity observations, in a $5-36 \mathrm{mmol} \mathrm{mol}^{-1}$ range.

In order to report humidity when the Picarro is not working, the meteorological sensor data are homogenized using Eq. (4). Our final humidity data set is composed of an average of Picarro and meteorological sensor corrected values.

\subsection{Lagrangian moisture source diagnostic}

The origin and transport of water vapour to Ivittuut is studied using a Lagrangian moisture source diagnostic (Sodemann 
et al., 2008b). Air parcels are traced backward from a box over Ivittuut $\left(61.0^{\circ} \mathrm{N}, 48.9^{\circ} \mathrm{W}\right.$ to $61.4^{\circ} \mathrm{N}, 47.8^{\circ} \mathrm{W}$ and from 0 to $500 \mathrm{~m}$ a.g.l.) with a $3 \mathrm{~h}$ timestep for 10 days. Parcel trajectories have been calculated using the FLEXPART model v8.1 (Stohl et al., 2005), forced by ECMWF ERAInterim reanalysis data, similar to the setup described in Sodemann and Stohl (2009). Moisture origin is then diagnosed from specific humidity increases from one time step to the next along the air parcel trajectories, and made quantitative by relating the increase to the total humidity in the air parcel, and any precipitation events occurring en route. Further details on the method are available in Sodemann et al. (2008b).

From this water transport simulation, the "moisture uptake" is computed as the amount of water injected in the air masses within the boundary layer, then going to Ivittuut, for each horizontal grid cell, and reported in $\mathrm{mm} \mathrm{day}^{-1}$. This can be interpreted as the contribution of total evaporation at the moisture sources to water vapour in Ivittuut.

\subsection{Water isotope enabled AGCM}

The use of an isotope enabled AGCM provides us with additional large-scale information for interpretation of our local observations. Simulations of atmospheric water vapour isotopic composition are extracted from the isotope enabled version of LMDZ4 (Hourdin et al., 2006), named LMDZiso and developed at the Laboratoire de Météorologie Dynamique (LMD) by Risi et al. (2010a). Model inter-comparisons conducted against data acquired at NEEM showed that the performance of LMDZiso is similar to that of other models at the seasonal and inter-annual scales (Steen-Larsen et al., 2011, 2013). It has been used over Greenland by Casado et al. (2012) to assess the impact of precipitation intermittency on NAO-temperature signals and by Ortega et al. (2014) to characterize the influence of weather regimes on ice core signals.

The model has a uniform resolution of $3.75^{\circ}$ in longitude and $2.5^{\circ}$ in latitude and 19 vertical levels. The simulation was nudged by three-dimensional fields of horizontal winds of ECMWF operational analyses for the period after 2002, and of ERA-40 for the period 1961-1974, ensuring realistic synoptic and long-term variability. Risi et al. (2010a) observed no noticeable discontinuity linked to the change of nudging atmospheric data.

Daily outputs, for comparison with Ivittuut observations, are provided for the September 2011 to December 2012 period. Monthly outputs over the 1961-1974 period are used for comparison with GNIP/IAEA data presented in Supplement Sect. A. Hereafter, grid cell coordinates correspond to the western border of the cell for longitudes, and to the center of the cell for latitudes (LMDZiso model convention). For the comparison of daily outputs with Ivittuut observations (Sect. 4.1), we use LMDZiso model outputs from two different grid cells: the ice sheet grid cell closest to the station $\left(62.11^{\circ} \mathrm{N}, 48.75^{\circ} \mathrm{W}\right)$, hereafter called
"Ivittuut terrestrial grid cell", and the nearest oceanic grid cell $\left(62.11^{\circ} \mathrm{N}, 52.5^{\circ} \mathrm{W}\right)$ located in the Labrador sea, hereafter called "nearest oceanic grid cell". Outputs from the lowermost model layer are used. Over Greenland, the top of this first layer is at about $15 \mathrm{hPa}$ above the ground level.

\section{Results: stable water isotopes, local climate and moisture transport}

Hourly averaged measurements of $\delta \mathrm{D}_{\mathrm{v}}$ and $\delta^{18} \mathrm{O}_{\mathrm{v}}$ over the complete observation period show a slope of $6.8 \% 0 \% 0^{-1}$ $\left(R^{2}=0.97 ; N=7889\right)$, which is close to the $6.5 \% 0 \% o^{-1}$ value reported by Steen-Larsen et al. (2013) for central Greenland in summer.

Figure 5 presents the time series of all validated hourly observations at Ivittuut station. We observe small diurnal variations in summer (Sect. 3.1). Synoptic variations are reported throughout the year on meteorological parameters and isotopes (Sect. 3.2), with particularly strong heat waves in summer 2012 (Sect. 3.3). Seasonal variations with similar magnitudes as synoptic variations are observed with different timings of extrema for $\delta^{18} \mathrm{O}_{\mathrm{v}}$ and $d_{\mathrm{v}}$ (Sect. 3.4). Given the length of our record, the mean seasonal cycle is affected by the particular events occurring during the year.

The water vapour isotopic content variations are compared to variations of precipitation isotopic content in Sect. 3.5. Then, the statistical relationships between Ivittuut water vapour isotopic composition and meteorological parameters are described in Sect. 3.6.

\subsection{Diurnal variability}

During the summer months (June to August), a diurnal cycle is observed in humidity mixing ratio, $\delta^{18} \mathrm{O}_{\mathrm{v}}$ and $d_{\mathrm{v}}$ when no large pressure change is observed. This was the case during 35 days in summer 2012 from June to August (16-28 June, 16-20 July, 22-27 July and 14-26 August). Figure 5f-j depicts a close-up of 21-23 August 2012, where a diurnal cycle is observed. The amplitude of the diurnal cycle is of about $1 \mathrm{mmol} \mathrm{mol}^{-1}$ on humidity mixing ratio, $1 \%$ on $\delta^{18} \mathrm{O}_{\mathrm{v}}$ and $5 \% \circ$ on $d_{\mathrm{v}}$. The minima and maxima occur respectively around 08:00 and 18:00 UTC (05:00 and 15:00 LT) for temperature and humidity mixing ratio, at 00:00 and 12:00 UTC (21:00 and 09:00 LT) for $\delta^{18} \mathrm{O}$, and at 00:00 and 18:00 UTC (21:00 and 15:00 LT) for $d_{\mathrm{v}}$.

These amplitudes of diurnal variations are on the same order of magnitude as those found by Welp et al. (2012) for six mid-latitude continental sites in different environments (forest, urban, grassland and agricultural land). Welp et al. (2012) linked the diurnal variations to plant transpiration and boundary layer dynamics. The amplitudes of the diurnal variations are also similar to those of Steen-Larsen et al. (2013) at the NEEM site in terms of $d_{\mathrm{v}}$, but lower for humidity and $\delta^{18} \mathrm{O}$. For the NEEM site, these variations are attributed to 


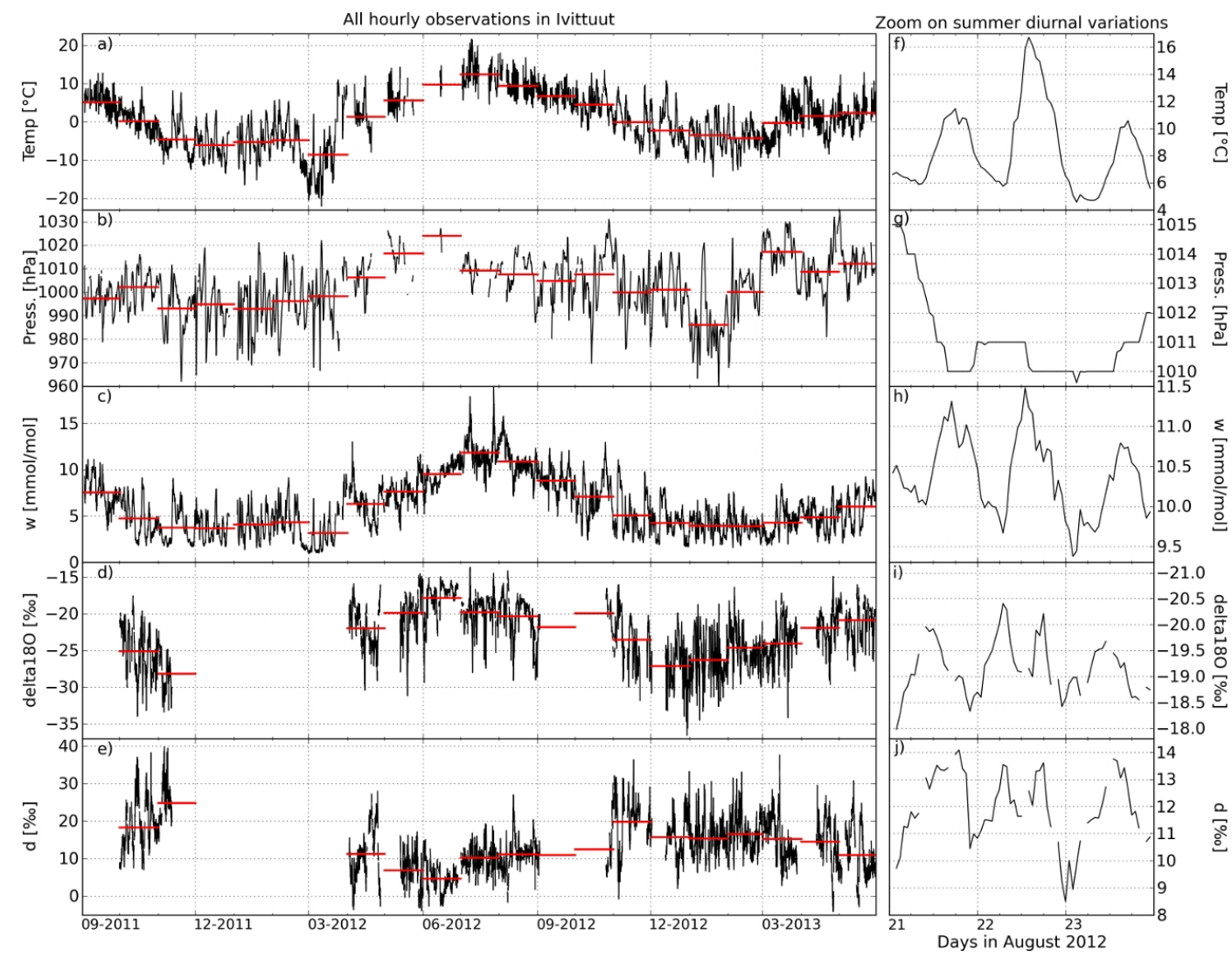

Fig. 5. Hourly observations time series in Ivittuut from the Picarro instrument and meteorological measurements (black). Monthly averages are shown as red bars. Left column panels: data from 21 September 2011 to 31 May 2013. Right column panels: data from 21 to 23 August 2013. Time is in UTC. Top to bottom panels: temperature $\left({ }^{\circ} \mathrm{C}\right)(\mathbf{a}, \mathbf{f})$, pressure $(\mathrm{hPa})(\mathbf{b}, \mathbf{g})$, humidity mixing ratio averaged from Picarro and meteorological sensor corrected values $\left(\mathrm{mmol}_{\text {water }} \mathrm{mol}_{\text {dry air }}^{-1}\right)(\mathbf{c}, \mathbf{h}), \delta^{18} \mathrm{O}(\% \circ)(\mathbf{d}, \mathbf{i})$ and $d(\% \circ)(\mathbf{e}, \mathbf{j})$. Note that the right and left graphs have different vertical scales.

exchanges of humidity between the air and the snow surface, and also boundary layer dynamics. In our case, the effects of surface fluxes (plant transpiration, snow-air exchanges) are probably less important than the influence of the advection of marine humidity. Further analysis of the boundary layer processes is limited by the lack of monitoring of the boundary layer height.

The diurnal cycle is generally smaller than the day-today variations which are governed by large-scale advection processes.

\subsection{Synoptic timescale variability and moisture source diagnostic}

In this section, we focus on the variations occurring at a timescale of a few days (synoptic events). Several events of humidity increase were observed, related to low-pressure systems. We selected 14 events based on an automatic criterion of humidity increase higher than $3 \mathrm{mmol} \mathrm{mol}^{-1}$ within 2 days. One event was selected in summer season, 5 events in autumn, 4 in winter and 4 in spring. Figure 6 presents the time series of meteorological and isotopic anomalies during
4 days surrounding each event. A composite synoptic event is calculated as an aggregation of all events (black line on Fig. 6). This composite event depicts an increase in temperature $\left(+7^{\circ} \mathrm{C}\right)$, humidity $\left(+4 \mathrm{mmol} \mathrm{mol}{ }^{-1}\right)$ and isotopes $\left(+5 \%\right.$ in $\left.\delta^{18} \mathrm{O}_{\mathrm{v}}\right)$, as well as a decrease in atmospheric pressure $(-9 \mathrm{hPa})$ and in $d_{\mathrm{v}}(-15 \%)$.

Figure 7 presents the daily moisture uptake and the sea level pressure, averaged from the different events, from $\mathrm{D}-3$ to $\mathrm{D}+1$, where $\mathrm{D}+0$ corresponds to the time of the humidity increase. Only the first eight events are used, as the backtrajectory simulation ends on 31 December 2012. The same time scale is used as for the composite series of Fig. 6. These events correspond to the arrival of a low-pressure system in southern Greenland (see mean sea level pressure map, Fig. 7). At D-3, moisture is mainly coming from North Atlantic (around Iceland) and the Labrador Sea. Between D-2 and $\mathrm{D}+0$, there is a strong increase in moisture uptake further south over the Atlantic Ocean, along the low-pressure cell. At $\mathrm{D}+1$, this southern moisture uptake vanishes, and the influences of North Atlantic and Labrador Sea sources increase again. The change in moisture origin observed during 


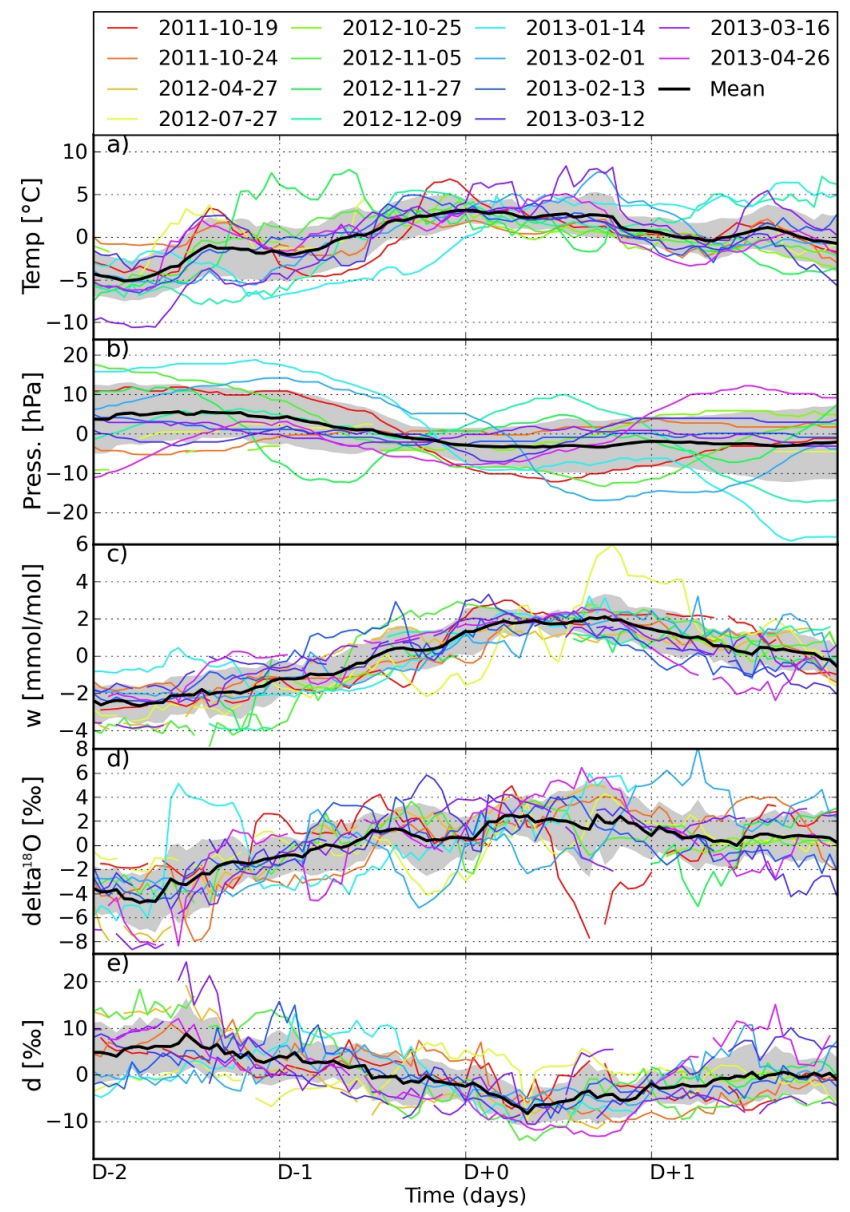

Fig. 6. Four-day time series of 14 synoptic events (colour curves) observed at Ivittuut station and composite event mean value (thick black curve) and standard deviation (grey shade). Anomalies are calculated as the difference between hourly values and the averaged values over the 4 days surrounding the humidity increase. Top to bottom: temperature $\left({ }^{\circ} \mathrm{C}\right)$, pressure $(\mathrm{hPa})$, humidity $\left(\mathrm{mmol}_{\text {water }} \mathrm{mol}_{\text {dry air }}^{-1}\right), \delta^{18} \mathrm{O}(\% \circ)$ and $d(\% o)$.

this high humidity spike probably explains the large variability of $d_{\mathrm{v}}$ values. Section 4.4 investigates the relationship between $d_{\mathrm{v}}$ and surface climate in the area of strong moisture uptake in the Atlantic (south of Greenland).

\subsection{Summer 2012 heat wave}

In summer 2012, successive strong heat waves have been observed in Ivittuut (Fig. 5) and over all Greenland, which led to a record melt of the Greenland ice sheet accentuated by positive feedbacks from changes in snow albedo and liquid cloud content (Fettweis et al., 2013; Bennartz et al., 2013; Nghiem et al., 2012; Neff et al., 2013). During these events, very high humidity spikes are observed in our records, whereas the associated signal of $\delta^{18} \mathrm{O}_{\mathrm{v}}$ is small compared to usual synoptic variations. Moisture source analysis

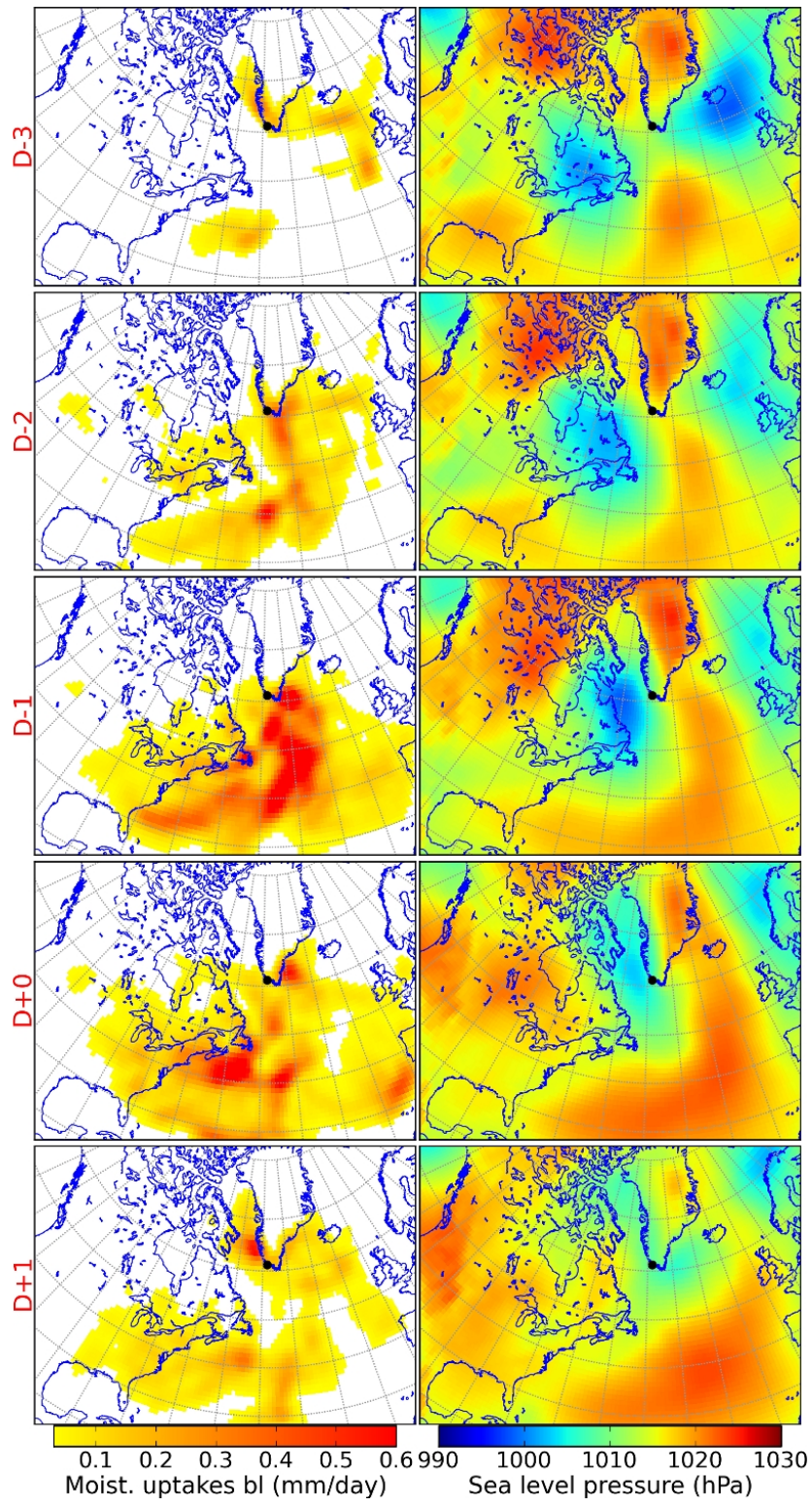

Fig. 7. Moisture uptake sources in $\mathrm{mm} \mathrm{day}^{-1}$ for air masses arriving in Ivittuut (left panels) and sea level pressure from ECMWF ERA-Interim reanalyses (right panels) during 5 days surrounding eight synoptic events in the period 21 September 2011 to 31 December 2012.

(not shown here) confirms dry air back-trajectory simulations by Neff et al. (2013) and reveals that these events are associated with dry air coming from North America, shifting towards the western subtropical Atlantic, where moisture uptake takes place, further transported towards southern Greenland. The Greenland melt event is therefore associated with a long-distance transport path, associated with on-way distillation and leading to relatively low $\delta^{18} \mathrm{O}_{\mathrm{v}}$ levels despite high local humidity values. 
Table 3. Statistics of $\delta^{18} \mathrm{O}_{\mathrm{v}}, d_{\mathrm{v}}$, temperature $(T)$, humidity mixing ratio $(w)$ at Ivittuut station from hourly data from October 2011 to May 2013: monthly averages (Avg), minimal values (Min), maximal values (Max) and number of hourly data $(N)$ ). $N_{\text {iso }}$ corresponds to the number of $\delta^{18} \mathrm{O}_{\mathrm{v}}$ and $d_{\mathrm{v}}$ data, $N_{T}$ and $N_{w}$ correspond respectively to the number of $T$ and $w$ data.

\begin{tabular}{|c|c|c|c|c|c|c|c|c|c|c|c|c|c|c|c|}
\hline \multirow{2}{*}{ Month } & \multicolumn{3}{|c|}{$\delta^{18} \mathrm{O}_{\mathrm{v}}(\% \circ)$} & \multicolumn{3}{|c|}{$d_{\mathrm{V}}(\%)$} & \multirow{2}{*}{$N_{\text {iso }}$} & \multicolumn{4}{|c|}{$T\left({ }^{\circ} \mathrm{C}\right)$} & \multicolumn{4}{|c|}{$w\left(\mathrm{mmol} \mathrm{mol}^{-1}\right)$} \\
\hline & Avg & Min & Max & Avg & Min & Max & & Avg & Min & Max & $N_{T}$ & Avg & Min & Max & $N_{w}$ \\
\hline Oct 2011 & -25.1 & -34.0 & -17.6 & 18.4 & 6.2 & 38.3 & 682 & 0.2 & -6.0 & 9.2 & 720 & 4.6 & 1.5 & 8.6 & 682 \\
\hline Nov 2011 & -28.1 & -33.4 & -22.3 & 24.9 & 14.6 & 43.6 & 249 & -5.7 & -11.2 & -0.2 & 264 & 2.5 & 1.4 & 4.9 & 249 \\
\hline Apr 2012 & -21.9 & -30.4 & -15.9 & 11.4 & -3.6 & 28.0 & 542 & 1.5 & -8.0 & 12.0 & 297 & 6.4 & 2.7 & 13.0 & 604 \\
\hline May 2012 & -19.8 & -31.2 & -14.5 & 6.9 & -3.9 & 17.2 & 417 & 5.3 & -0.1 & 14.2 & 232 & 7.6 & 3.4 & 11.7 & 608 \\
\hline Jun 2012 & -17.8 & -29.4 & -14.9 & 4.7 & -3.9 & 15.1 & 602 & 9.7 & 6.6 & 14.7 & 34 & 9.5 & 5.2 & 12.0 & 647 \\
\hline Jul 2012 & -19.7 & -28.0 & -13.6 & 10.3 & 1.6 & 19.3 & 665 & 12.4 & 4.6 & 21.6 & 437 & 11.9 & 7.6 & 18.9 & 676 \\
\hline Aug 2012 & -20.3 & -29.1 & -14.1 & 11.2 & -1.7 & 27.1 & 681 & 9.5 & 3.6 & 17.9 & 548 & 10.9 & 6.6 & 15.9 & 687 \\
\hline Nov 2012 & -23.5 & -31.8 & -16.0 & 19.9 & -0.8 & 36.4 & 510 & -0.3 & -8.5 & 9.6 & 600 & 5.3 & 2.2 & 10.7 & 569 \\
\hline Dec 2012 & -27.1 & -36.6 & -19.3 & 15.8 & 2.0 & 27.4 & 468 & -2.2 & -10.7 & 10.7 & 744 & 4.2 & 1.5 & 8.1 & 567 \\
\hline Jan 2013 & -26.3 & -34.5 & -18.7 & 15.4 & 6.2 & 33.3 & 704 & -3.6 & -14.4 & 4.4 & 720 & 4.0 & 1.6 & 8.9 & 708 \\
\hline Feb 2013 & -24.6 & -30.3 & -16.3 & 16.6 & 7.0 & 33.1 & 627 & -4.3 & -12.8 & 4.8 & 672 & 4.2 & 1.4 & 8.4 & 627 \\
\hline Mar 2013 & -24.0 & -34.2 & -17.2 & 15.2 & 2.8 & 37.7 & 605 & -0.7 & -9.5 & 9.7 & 672 & 4.2 & 1.6 & 8.2 & 605 \\
\hline Apr 2013 & -21.9 & -29.7 & -14.9 & 14.6 & -4.1 & 29.6 & 396 & -0.4 & -8.4 & 7.5 & 408 & 4.6 & 1.8 & 7.9 & 396 \\
\hline May 2013 & -20.9 & -27.8 & -16.0 & 11.0 & -3.0 & 33.7 & 592 & 2.6 & -4.8 & 12.9 & 624 & 6.3 & 2.7 & 8.6 & 592 \\
\hline
\end{tabular}

\subsection{Seasonal variability and moisture source diagnostic}

The mean values of $\delta^{18} \mathrm{O}_{\mathrm{v}}$ and $d_{\mathrm{v}}$ computed from full hourly data record are respectively of -22.7 and $13.6 \%$. From monthly averaged values of $\delta^{18} \mathrm{O}_{\mathrm{v}}$ and $d_{\mathrm{v}}$, presented in Table 3, we observe a seasonal amplitude of $10.3 \%$ of $\delta^{18} \mathrm{O}_{\mathrm{v}}$ and $20.2 \%$ for $d_{\mathrm{v}}$. Minima in $\delta^{18} \mathrm{O}_{\mathrm{v}}$ are observed in the period November-December, while maxima occur in JuneJuly. Regarding $d_{\mathrm{v}}$, minimum values are in May-June and the maximum in November. During autumn periods, $\delta^{18} \mathrm{O}_{\mathrm{v}}$ and $d_{\mathrm{v}}$ values are respectively approximately $5 \%$ below and $6-12 \%$ obove long-term mean values. Those extreme values are not always simultaneous. In 2011, extrema in $\delta^{18} \mathrm{O}_{\mathrm{v}}$ and $d_{\mathrm{v}}$ were both observed in November, whereas in 2012, they were respectively observed in December and November (Fig. 5d and e).

Moisture source diagnostic records over the four seasons in 2012 (Fig. 8) highlight seasonal shifts of moisture sources for Ivittuut, potentially influencing the observed water vapour isotopic signal in Ivittuut. In winter, sources are centered in the North Atlantic, south of Greenland. In spring and autumn, moisture also originates from the North American continent, together with a larger contribution from the subtropical ocean. In summer, the dominant moisture sources appear to be northeastern America and South Greenland. This is consistent with the long-distance transport from North America to southern Greenland identified in summer from pollen observations by Rousseau et al. (2003). Along trajectories from North America to the Atlantic Ocean, dry autumn air masses (compared to summer where evapotranspiration is more intense) could cause enhanced kinetic fractionation and contribute to the observed autumnal maximum in $d_{\mathrm{v}}$. High $d_{\mathrm{v}}$ values in autumn have already been observed in Arctic water

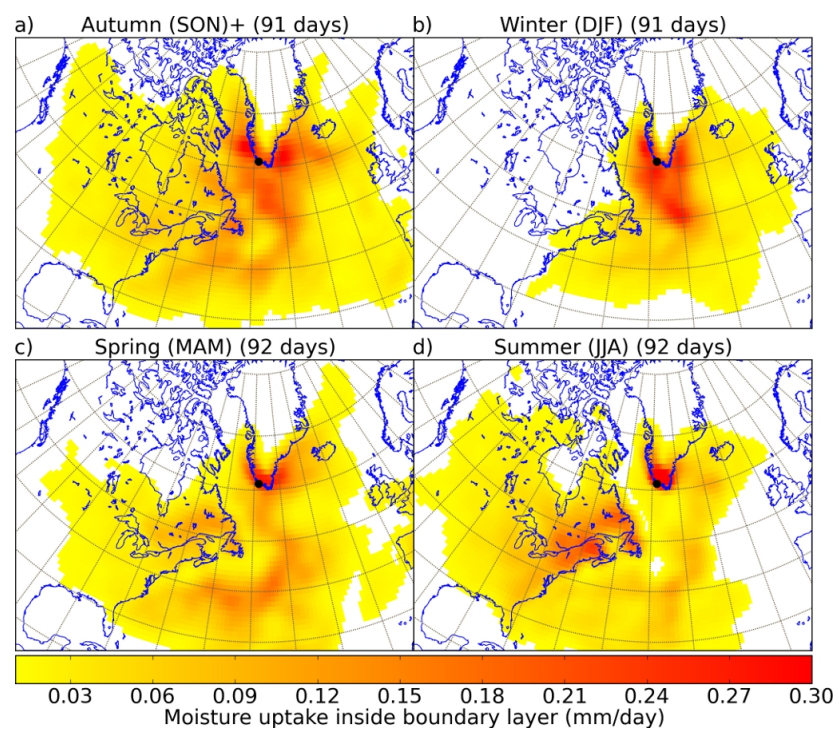

Fig. 8. Moisture uptake sources (in mm day ${ }^{-1}$ ) for air masses arriving in Ivittuut, averaged by season for year 2012.

vapour (Kurita, 2011), attributed to oceanic evaporation at the sea-ice border.

This motivates further investigation of the relationships between water vapour isotopes and local climate season by season, as described in Sect. 3.6.

\subsection{Precipitation isotopic composition and equilibrium with vapour}

Our precipitation data show a $\delta \mathrm{D}_{\mathrm{p}} / \delta^{18} \mathrm{O}_{\mathrm{p}}$ slope of $7.5 \% 0 \% o^{-1}\left(R^{2}=0.92, N=39\right)$. This is similar to the results 
obtained from high-latitude precipitation data, such as those from NEEM (Steen-Larsen et al., 2011).

We want to establish whether the water vapour is in isotopic equilibrium with the precipitation and is thus representative of the vapour used to form condensates. As described in Sect. 2.3, a theoretical water vapour isotopic composition is calculated from precipitation isotopic measurements, supposing phase change at equilibrium. Figure 9 presents the time series of the isotopic composition of the observed precipitation (denoted by subscript $p$ ), together with the observed water vapour (denoted in this section by subscript $\mathrm{v}$, obs) and with water vapour calculated at equilibrium with precipitation data (denoted by subscript v, eq), from November 2011 to December 2012.

Concerning precipitation isotopic measurements, $\delta^{18} \mathrm{O}_{\mathrm{p}}$ values are in the range of -20 to $-5 \%$, with quite low values compared to the GNIP/IAEA mean seasonal cycle (described in Supplement Sect. A). $d_{\mathrm{p}}$ varies from about -5 to $+20 \%$, with higher values for snow samples in autumn 2011, compared to the climatological average. During winter, snow precipitation samples show generally higher $d_{\mathrm{p}}$ than liquid precipitation. If the liquid (snow) samples correspond to liquid (ice) clouds, this $d_{\mathrm{p}}$ difference between snow and liquid samples might reflect the different equilibrium fractionation coefficients for solid or for liquid phases. Unfortunately, no direct cloud observations are available at Ivittuut. However, this hypothesis is consistent with remote sensing data suggesting the predominance of low-altitude clouds in this area (Liu et al., 2012).

A clear seasonal cycle can be seen for $\delta^{18} \mathrm{O}_{\mathrm{v}, \mathrm{eq}}$, with lower values in winter than in summer, which is consistent with the $\delta^{18} \mathrm{O}_{\mathrm{v}, \mathrm{obs}}$ seasonal cycle. The small magnitude of the seasonal cycle of precipitation $\delta^{18} \mathrm{O}_{\mathrm{p}}$ in the GNIP/IAEA longterm measurements (described in Supplement Sect. A) and in our precipitation data can now be understood through a large seasonal cycle in vapour $\delta^{18} \mathrm{O}_{\mathrm{v}}$, partly erased by the impact of seasonal variations of temperature on vapour to liquid (or solid) fractionation. Regarding $d_{\mathrm{v}, \mathrm{eq}}$, the seasonal cycle observed on water vapour measurements of $d_{\mathrm{v}, \mathrm{obs}}$ is partly reproduced by this theoretical vapour, with maximum values observed in autumn. We note that a 1-month lag between $d$ and $\delta^{18} \mathrm{O}$ of central Greenland surface snow has been depicted in shallow ice core seasonal cycles (Hoffmann et al., 1998). However, diffusion processes may affect the ice core record (Johnsen et al., 2000), which is not the case for our measurements. We finally note that the observed water vapour $d_{\mathrm{v}, \text { obs }}$ is located in between the theoretical values derived from liquid and solid samples.

We conclude from this comparison that surface water vapour may be at equilibrium with precipitation. While such equilibrium may arise from exchanges between rainfall and surface vapour, we cannot rule out that surface vapour may also be representative from moisture at the cloud altitude, in an area with a predominance of low-altitude clouds (Liu et al., 2012). Our comparison is nevertheless restricted by

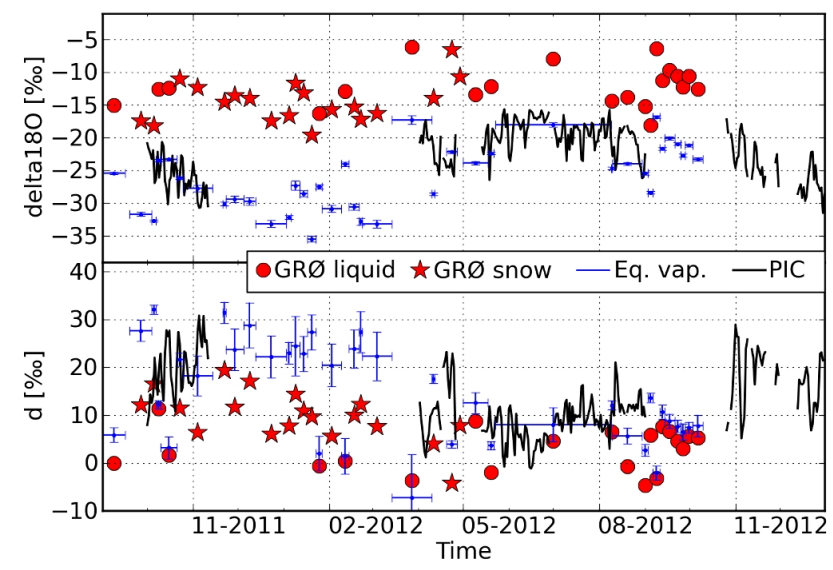

Fig. 9. Top panel, $\delta^{18} \mathrm{O}(\%)$; bottom panel, $d(\%)$. Black curves represent water vapour observations daily averaged values $\left(\delta_{\mathrm{V}}\right.$ and $\left.d_{\mathrm{V}}\right)$; red circles and stars represent precipitation samplings isotopic composition liquid and snow samples respectively $\left(\delta_{\mathrm{p}}\right.$ and $\left.d_{\mathrm{p}}\right)$; blue crosses represent water vapour isotopic composition calculated from precipitation measurements supposing phase change at equilibrium $\left(\delta_{\mathrm{v}, \mathrm{eq}}\right.$ and $\left.d_{\mathrm{v}, \mathrm{eq}}\right)$, with associated standard deviation taking into account standard deviation on temperature and precision of precipitation isotopic composition measurement.

the lack of direct observations of cloud height and types of condensates.

\subsection{Statistical relationships between water vapour isotopes and local climate}

We now explore the relationships between $\delta^{18} \mathrm{O}_{\mathrm{v}}$ and local climate parameters on different timescales. In this section, linear statistical analyses are conducted, and correlation coefficients $(R)$ and slopes are reported (see Table 4).

From all daily data, the linear regression between $\delta^{18} \mathrm{O}_{\mathrm{v}}$ and local temperature gives a low slope of $0.37 \% 0^{\circ} \mathrm{C}^{-1}$ ( $R=0.65, N=282$, see Fig. 10a). Note that, for Rayleigh distillation, the slope between water vapour and temperature is very close to the slope between precipitation isotopic composition and temperature. For Ivittuut, the slope obtained for vapour is at the lowest end of the slopes usually obtained for precipitation $\delta^{18} \mathrm{O}$ and temperature relationships: for ice core reconstructed $\delta^{18} \mathrm{O}$ and temperatures (Vinther et al., 2010; Masson-Delmotte et al., 2011; Kindler et al., 2013), or for isotopically enabled atmospheric models simulations (Sime et al., 2013). It is also two times lower than the spatial relationship observed on the Greenland ice sheet (Sjolte et al., 2011). A stronger linear correlation is observed between $\delta^{18} \mathrm{O}_{\mathrm{v}}$ and humidity mixing ratio $w$ over the complete series $(R=0.78, N=351$, Fig. 10c). The best correlation with humidity is obtained using a log-linear relationship ( $R=0.82, N=351$ ). The corresponding regression equation giving $\delta^{18} \mathrm{O}_{\mathrm{v}}$ in \%o as a function of $w$ in $\mathrm{mmol} \mathrm{mol}^{-1}$ is

$\delta^{18} \mathrm{O}_{\mathrm{v}}=-33.0+5.9 \ln (w)$. 

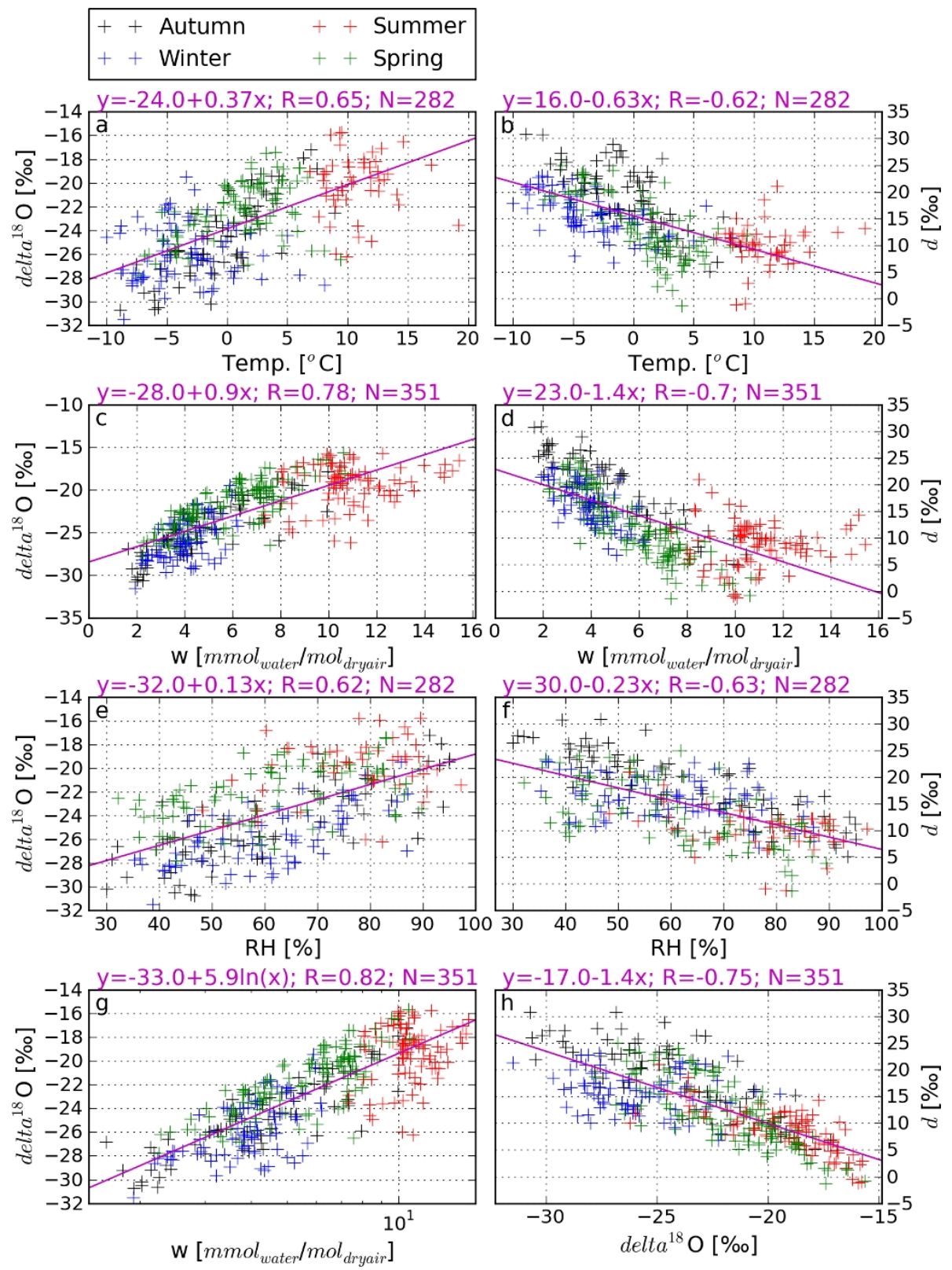

Fig. 10. Crosses: daily averaged observations at Ivittuut station from 21 September 2011 to 31 May 2013 for spring (green), summer (red), autumn (black) and winter (blue). Magenta: linear regression curves (or log-linear regression for $\mathbf{g}$ ). $\delta^{18} \mathrm{O}_{\mathrm{v}}\left(\%\right.$ ) vs. temperature $\left({ }^{\circ} \mathrm{C}\right)(\mathbf{a})$, $d_{\mathrm{v}}(\%)$ vs. temperature $\left({ }^{\circ} \mathrm{C}\right)(\mathbf{b}), \delta^{18} \mathrm{O}_{\mathrm{v}}(\% o)$ vs. $w\left(\mathrm{mmol}_{\mathrm{water}} \mathrm{mol}_{\text {dry air }}^{-1}\right)(\mathbf{c}), d_{\mathrm{v}}(\%)$ vs. $w\left(\mathrm{mmol}_{\text {water }} \mathrm{mol}_{\text {dry air }}^{-1}\right)(\mathbf{d}), \delta^{18} \mathrm{O}_{\mathrm{v}}(\%)$ vs. $\mathrm{RH}$ $(\%)(\mathbf{e}), d_{\mathrm{v}}(\%)$ vs. $\mathrm{RH}(\%)(\mathbf{f}), \delta^{18} \mathrm{O}_{\mathrm{v}}(\%)$ vs. $w\left(\mathrm{mmol}_{\mathrm{water}} \mathrm{mol}_{\text {dry air }}^{-1}\right.$ in $\log$ scale (g), $\delta^{18} \mathrm{O}_{\mathrm{v}}(\% \circ)$ vs. $d_{\mathrm{v}}(\% o)(\mathbf{h})$, (i).

This result is consistent with Rayleigh distillation during air mass advection, with similar coefficients as calculated by Lee et al. (2006) for a 1-year observation period in New Haven.

Beyond the correlation between $\delta^{18} \mathrm{O}$ and Ivittuut relative humidity $(R=0.62, N=282)$, we observe that, for a given level of humidity, $\delta^{18} \mathrm{O}$ is higher in spring-summer and more depleted in autumn-winter (Fig. 10c, e and g). Moreover, seasonal maxima and minima do not occur in phase for $\delta^{18} \mathrm{O}$ and local relative humidity.
Within a given season, we explore the relationships at the synoptic timescale (see Table 4) between surface water vapour isotopic composition and local climate. Anomalies are computed against the 15-day running average in order to remove seasonal effects. The relationships are computed for the four seasons, based on daily averaged values: Spring (March, April, May), Summer (June, July, August), Autumn (September, October, November), Winter (December, January, February). We first observe a strong correlation 
Table 4. Values of slopes, correlation coefficients $(R)$ and number of data points $(N)$ for relationships between $\delta^{18} \mathrm{O}_{\mathrm{v}}$ and temperature, $\delta^{18} \mathrm{O}_{\mathrm{v}}$ and the logarithm of humidity mixing ratio, $d_{\mathrm{v}}$ and temperature, $d_{\mathrm{v}}$ and $\delta^{18} \mathrm{O}_{\mathrm{v}}, d_{\mathrm{v}}$ and relative humidity. These values are computed for different timescales using different average data frequencies (from left to right): for the observed diurnal cycle (from 21 to 23 August 2012 data) based on hourly data, for the composite synoptic event based on hourly data, for the four seasons based on daily detrended data (anomalies from 15-day running average data) from 21 September 2011 to May 2013, for the complete observation period from 21 September 2011 to May 2013 based on daily data, and for daily LMDZiso outputs at Ivittuut terrestrial grid cell from 21 September 2011 to May 2013.

\begin{tabular}{|c|c|c|c|c|c|c|c|c|c|}
\hline & & \multicolumn{7}{|c|}{ Observations } & \multirow{3}{*}{$\begin{array}{l}\text { LMDZiso } \\
\text { Complete } \\
\text { period } \\
\text { (daily) }\end{array}$} \\
\hline & & \multirow{2}{*}{$\begin{array}{l}\text { Diurnal } \\
\text { cycle } \\
\text { (hourly) }\end{array}$} & \multirow{2}{*}{$\begin{array}{l}\text { Composite } \\
\text { event } \\
\text { (hourly) }\end{array}$} & \multicolumn{4}{|c|}{$\begin{array}{l}\text { Detrended signal on one season } \\
\text { (daily) }\end{array}$} & \multirow{2}{*}{$\begin{array}{l}\text { Complete } \\
\text { period } \\
\text { (daily) }\end{array}$} & \\
\hline & & & & Spring & Summer & Autumn & Winter & & \\
\hline \multirow{3}{*}{$\delta^{18} \mathrm{O} / T$} & Slope & -0.01 & 0.76 & 0.25 & -0.20 & 0.73 & 0.03 & 0.37 & 0.28 \\
\hline & $R$ & -0.06 & 0.91 & 0.35 & -0.16 & 0.63 & 0.04 & 0.65 & 0.48 \\
\hline & $N$ & 64 & 97 & 89 & 50 & 67 & 76 & 282 & 467 \\
\hline \multirow{3}{*}{$\delta^{18} \mathrm{O} / \ln (w)$} & Slope & 2.3 & 6.2 & 6.0 & 9.0 & 5.5 & 5.2 & 5.9 & 4.4 \\
\hline & $R$ & 0.18 & 0.95 & 0.69 & 0.46 & 0.78 & 0.59 & 0.82 & 0.7 \\
\hline & $N$ & 64 & 97 & 117 & 88 & 70 & 76 & 351 & 467 \\
\hline \multirow{3}{*}{$d_{\mathrm{V}} / T$} & Slope & 0.19 & -1.46 & -1.15 & 0.55 & -2.11 & -0.64 & -0.63 & -0.056 \\
\hline & $R$ & 0.43 & -0.84 & -0.64 & 0.32 & -0.76 & -0.57 & -0.62 & -0.13 \\
\hline & $N$ & 64 & 97 & 89 & 50 & 67 & 76 & 282 & 467 \\
\hline \multirow{3}{*}{$d_{\mathrm{v}} / \delta^{18} \mathrm{O}$} & Slope & -1.60 & -1.87 & -1.76 & -0.92 & -1.85 & -0.34 & -1.40 & -0.55 \\
\hline & $R$ & -0.65 & -0.90 & -0.73 & -0.65 & -0.77 & -0.20 & -0.75 & -0.72 \\
\hline & $N$ & 64 & 97 & 117 & 88 & 70 & 76 & 351 & 467 \\
\hline \multirow{3}{*}{$d_{\mathrm{V}} / \mathrm{RH}$} & Slope & -0.04 & -0.30 & -0.20 & -0.18 & -0.29 & -0.09 & -0.23 & -0.10 \\
\hline & $R$ & -0.37 & -0.95 & -0.56 & -0.64 & -0.85 & -0.32 & -0.63 & -0.55 \\
\hline & $N$ & 64 & 97 & 89 & 50 & 67 & 76 & 282 & 467 \\
\hline
\end{tabular}

between $\delta^{18} \mathrm{O}_{\mathrm{v}}$ and temperature in autumn $(R=0.63, N=67$, slope $0.7 \% 0^{\circ} \mathrm{C}^{-1}$ ) which is weaker in spring and vanishes in summer and winter. The relationship between $\delta^{18} \mathrm{O}_{\mathrm{v}}$ and the logarithm of specific humidity is more robust throughout autumn, winter and spring than during summer, where we have reported a decoupling during the heat wave event (see also Sect. 3.3). A strong anti-correlation between $d_{\mathrm{v}}$ and $\delta^{18} \mathrm{O}_{\mathrm{v}}$ is seen in spring, summer and autumn, but is reduced in winter. We conclude from Table 4 that the strongest correlations between $\delta^{18} \mathrm{O}_{\mathrm{v}}$ and temperature or the logarithm of humidity and between $d_{\mathrm{v}}$ and relative humidity are observed in autumn, marked by large-amplitude synoptic events. Note that the relationship between $d_{\mathrm{v}}$ and North Atlantic relative humidity is investigated in Sect. 4.4.

Interestingly, the statistical relationships observed in autumn are also closest to those extracted from the composite synoptic event, based on hourly averaged values (Table 4, Sect. 3.2). The overall correlations reported from all daily data therefore combine two effects, one linked with seasonal cycles and another one linked with synoptic events (with higher $\delta^{18} \mathrm{O}_{\mathrm{v}}$-temperature slopes), clearly visible within autumn data. Longer records will be needed to deconvolve these two effects.

Finally, we note that different patterns emerge from diurnal cycles, based on hourly averaged data, where our statistical analysis only reveals a significant anti-correlation between $d_{\mathrm{v}}$ and $\delta^{18} \mathrm{O}_{\mathrm{v}}$.

\section{Discussion: comparison with LMDZiso simulations}

In this section, Ivittuut observations are compared to LMDZiso simulations in order to test the realism of these simulations, to provide large-scale information for the interpretation of our observations and to estimate the spatial representativeness of our observations. The comparison of LMDZiso and GNIP/IAEA climatologies (presented in Supplement Sect. A) shows that LMDZiso has a cold bias and overestimates precipitation amount. For precipitation isotopic composition, the simulated $\delta^{18} \mathrm{O}_{\mathrm{p}}$ values are too depleted, consistent with climate biases. Moreover, LMDZiso strongly underestimates the magnitude of $d_{\mathrm{p}}$ seasonal variations.

Section 4.1 compares our observations with outputs from the model first vertical level. Section 4.2 is dedicated to relationships between simulated water vapour and local climate variables. Section 4.3 investigates the spatial representativeness of our observations, and Sect. 4.4 focuses on the influence of relative humidity at the moisture source on $d_{\mathrm{v}}$. 


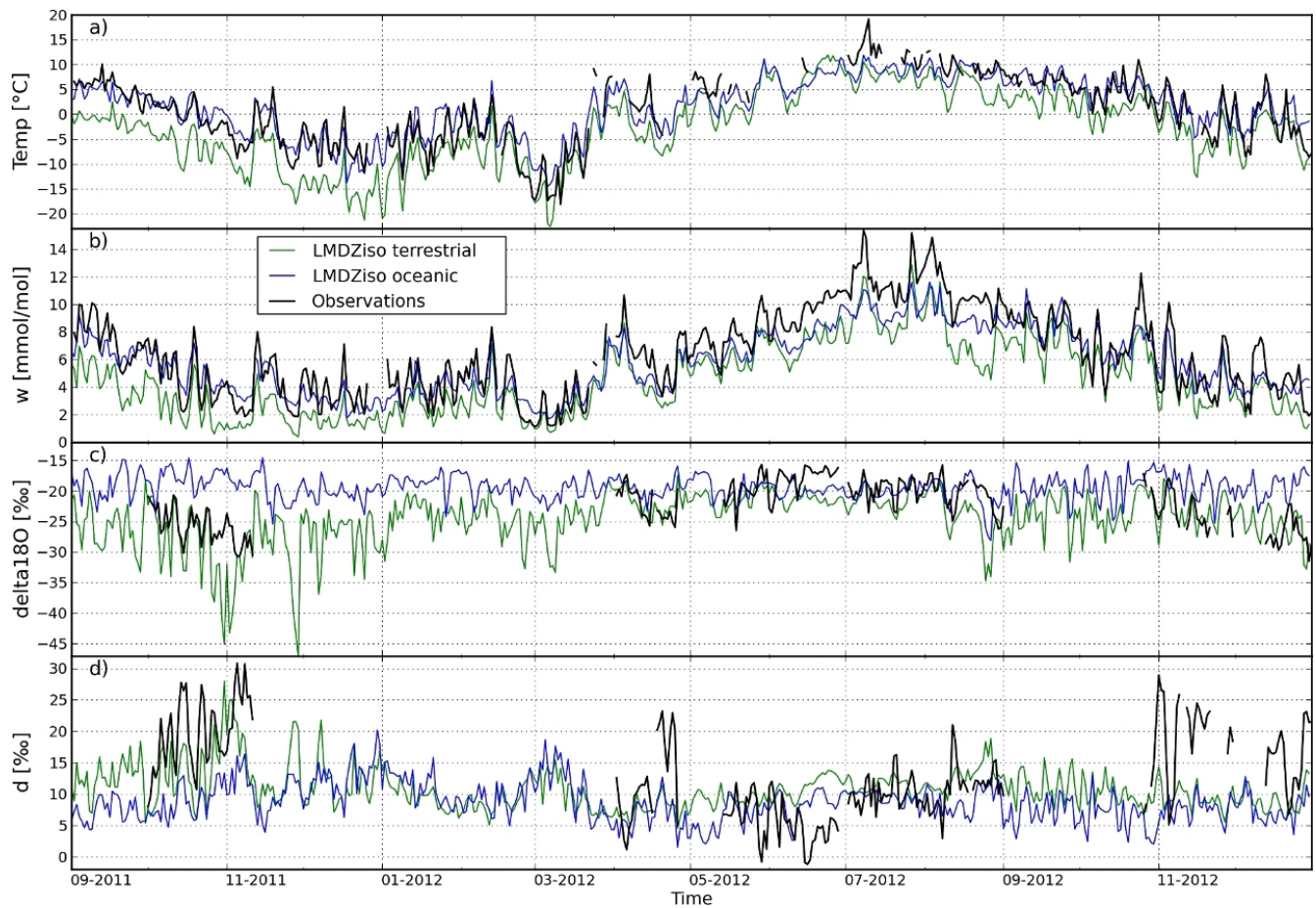

Fig. 11. Time series (from 1 September 2011 to 31 December 2012) of LMDZiso at Ivittuut terrestrial grid cell $\left(62.11^{\circ} \mathrm{N}, 48.75^{\circ} \mathrm{W}\right)($ green curves), LMDZiso at the nearest oceanic grid cell $\left(62.11^{\circ} \mathrm{N}, 52.5^{\circ} \mathrm{W}\right.$ (blue curves) and observations in Ivittuut (black curves). Temperature $\left({ }^{\circ} \mathrm{C}\right)(\mathbf{a})$, humidity mixing ratio $\left(\mathrm{mmol}_{\text {water }} \mathrm{mol}_{\text {dry air }}^{-1}\right)(\mathbf{b}), \delta^{18} \mathrm{O}(\% \circ)(\mathbf{c})$ and $d(\% \circ)(\mathbf{d})$. Observed humidity mixing ratio is computed as the average from Picarro and meteorological sensor derived measurements.

\subsection{Comparison of LMDZiso lowest layer isotopic composition with Ivittuut observations at synoptic and seasonal scales}

Figure 11 presents the daily averaged time series of Ivittuut observations, compared to both oceanic and Ivittuut terrestrial grid cells model output.

The Ivittuut terrestrial grid cell shows a cold and dry bias (in terms of $w$ ), probably explained by the grid size covering part of the ice cap (orography and land sea masks do not exactly represent the situation of the station). The nearest oceanic grid cell represents well temperature and humidity mean levels and seasonal cycles, with smaller temperature variability linked with ocean inertia. For $\delta^{18} \mathrm{O}_{\mathrm{v}}$, the variations of both model grid cells are close, but the magnitude of these variations are larger on the Ivittuut terrestrial grid cell. The seasonal variability is better represented by the Ivittuut terrestrial grid cell. The oceanic grid cell shows too smooth $\delta^{18} \mathrm{O}_{\mathrm{v}}$ variations, possibly due to insufficient distillation (driven by air temperature variations). For both model grid cells, LMDZiso strongly underestimates the synoptic and seasonal variability of $d_{\mathrm{v}}$. This was also observed at NEEM site by Steen-Larsen et al. (2013) for Arctic air masses and in Saclay (France, $20 \mathrm{~km}$ southwest of Paris) by Risi et al. (2010a).
For all parameters except $d_{\mathrm{v}}$, the synoptic variability is well represented by the Ivittuut terrestrial grid cell. For some periods (25 October to 5 November 2011 and 11 to $27 \mathrm{Au}-$ gust 2012), the discrepancies between Ivittuut terrestrial grid cell and observations increase and the variations are better represented by the nearest oceanic grid cell, or eventually by a weighted average of both nearest oceanic and Ivittuut terrestrial grid cells. This highlights the need for downscaling methodologies in order to make best use of such station data. Simulations performed at a spatial resolution smaller than the distance from the ocean to the ice cap $(\sim 20 \mathrm{~km})$ would help to solve this problem.

\subsection{Statistical relationships with local climatic parameters in LMDZiso}

The correlations between isotopic values and local meteorological parameters have been computed from daily LMDZiso outputs at the Ivittuut terrestrial grid cell from 21 September 2011 to 31 December 2012, for comparison with correlations obtained for observations (see Sect. 3.6). These correlations are presented for the whole data set in the rightmost column of Table 4 .

The $\delta D_{v}-\delta^{18} \mathrm{O}_{\mathrm{v}}$ slope (not presented in Table 4) is higher in LMDZiso simulations than in observations ( 7.5 for LMDZiso against $6.8 \% \%^{-1}$ for observations) and the 
correlation is similar $\left(R^{2}=0.99, N=488\right.$ in LMDZiso). The $\delta^{18} \mathrm{O}_{\mathrm{v}}-w$ relationship in the model is best reproduced by a $\log$-linear function $(R=0.7, N=467)$, as seen for observations, reproducing the influence of Rayleigh distillation on $\delta^{18} \mathrm{O}_{\mathrm{v}}$, although with a lower slope than observed.

We have already seen that LMDZiso underestimates $d_{\mathrm{v}}$ variability. As a result, the relationships between $d_{\mathrm{v}}$ in LMDZiso and other parameters lead to lower slopes compared to observations. The correlation becomes low with temperature and $w$, compared to observations. The model nevertheless produces a strong anti-correlation between $d_{\mathrm{v}}$ and $\delta^{18} \mathrm{O}_{\mathrm{v}}$, although with a lower slope $\left(-0.55 \% \%^{-1}\right)$ than observed.

\subsection{Spatial representativeness of Ivittuut observations in LMDZiso}

Figure 12 shows correlation coefficient maps between Ivittuut observations and model outputs of surface air temperature, relative humidity, $\delta^{18} \mathrm{O}_{\mathrm{v}}$ and $d_{\mathrm{v}}$, calculated from daily values from 21 September 2011 to 31 December 2012. For temperature and $\delta^{18} \mathrm{O}_{\mathrm{v}}$, the correlations are high at Ivittuut terrestrial grid cell $(R=0.91, N=212$ and $R=0.63$, $N=219$, respectively) and over all Greenland. For $\delta^{18} \mathrm{O}_{\mathrm{v}}$, the correlation abruptly disappears at the nearest oceanic grid cell $(R=-0.21, N=219)$, consistent with the different behaviours between oceanic and continental grid cells, as previously seen from Fig. 11. The reason for this strong spatial structure remains unexplained. Concerning relative humidity and $d_{\mathrm{v}}$, the maxima of correlation between the model and our observations are not located around the station, but over the Atlantic Ocean, in the region represented by the blue square in Fig. 12 (lower right box). Hereafter, we call "Zone 1" this Atlantic region going from $49.44^{\circ} \mathrm{N}, 41.25^{\circ} \mathrm{W}$ to $59.58^{\circ} \mathrm{N}$, $22.5^{\circ} \mathrm{W}$ approximately. From FLEXPART back-trajectories, we had seen that this region of high correlation is an important moisture source for our station (Figs. 7 and 8). The next section focuses on the impact on Ivittuut $d_{\mathrm{v}}$ of the meteorological conditions of this region.

\subsection{Relationships between deuterium excess and North Atlantic surface relative humidity}

Here, we investigate the relationships between Zone 1 relative humidity (normalized to sea surface temperature (SST), from LMDZiso data) and Ivittuut $d_{\mathrm{v}}$ (from observations and LMDZiso), summarized in Table 5. The observations show that $d_{\mathrm{v}}$ is closely related to relative humidity of Zone 1 (with a slope of $-1.1 \% \circ \%^{-1}$ ). This result is confirmed when using relative humidity from ECMWF data (not shown here). The strength of the correlation is similar to that observed in Israel vapour, compared to relative humidity at the surface of Mediterranean moisture sources (Pfahl and Wernli, 2008). Our methodology however differs as their calculation relies on the humidity at the exact source identified from
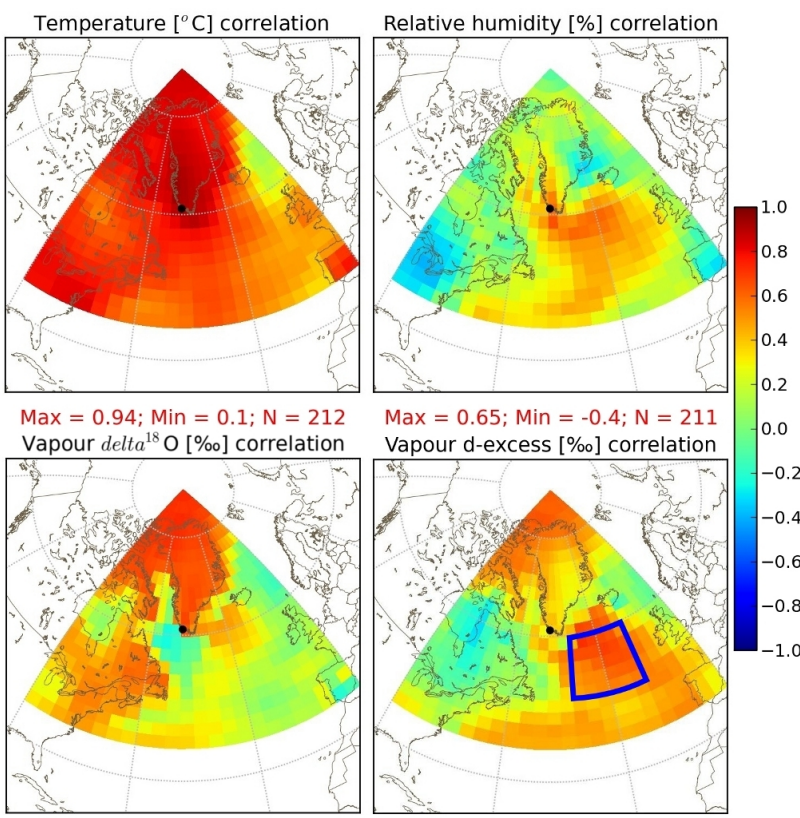

Max $=0.65 ;$ Min $=-0.4 ; \mathrm{N}=211$ Vapour d-excess [\%o] correlation

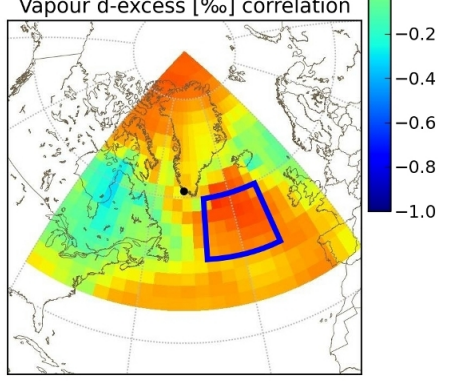

$\operatorname{Max}=0.73 ; \operatorname{Min}=-0.39 ; \mathrm{N}=219$

Fig. 12. Maps of correlations between Ivittuut daily observations and LMDZiso simulated daily values at different grid cells, for temperature, relative humidity, $\delta^{18} \mathrm{O}_{\mathrm{v}}$ and $d_{\mathrm{v}}$. Colour indicates $R$ correlation coefficient. Blue square on lower right box represents the region called "Zone 1".

each trajectory, while we used a fixed location. The slope that we obtain is higher than the slope found by Pfahl and Wernli (2008). It is also higher than the theoretical value (Merlivat and Jouzel, 1979) and the global empirical relationship observed from other studies (Pfahl and Sodemann, 2013). We have computed the correlation of $d_{\mathrm{v}}$ observed at Ivittuut with relative humidity in Zone 1, applying different time lags ( -5 to +5 days). The best result is obtained when no lag time is applied. We conclude that the transport of the signal from Zone 1 to Ivittuut occurs in less than $24 \mathrm{~h}$, consistent with FLEXPART back-trajectory analyses.

In LMDZiso, $d_{\mathrm{v}}$ in Zone 1 is closely anti-correlated with relative humidity at the ocean surface (with a slope of $-0.5 \% \%^{-1}$ ). This is consistent with the theoretical behaviour of evaporation. However, this link between the simulated $d_{\mathrm{v}}$ and Zone 1 relative humidity is lost during transportation to Ivittuut, as illustrated by the weak correlation between $d_{\mathrm{v}}$ simulated at Ivittuut and both Zone 1 relative humidity $(R=-0.28)$ and Ivittuut observed $d_{\mathrm{v}}(R=0.37)$. We therefore infer that LMDZiso loses part of the $d_{\mathrm{v}}$ source signal until air masses reach Ivittuut.

Figure 13 illustrates the fact that seasonal and synoptic variations of relative humidity in Zone 1 may explain the seasonal cycle of Ivittuut $d_{\mathrm{v}}$ and its lag with respect to the seasonal cycle of $\delta^{18} \mathrm{O}_{\mathrm{v}}$ or climate variables in Ivittuut, as well as its minimum summer variability. Half of the $d_{\mathrm{v}}$ 
Table 5. Correlation coefficients $R$ between the different data sets of relative humidity (RH) and $d_{\mathrm{V}}$ from observations, LMDZiso outputs at Ivittuut and in Zone 1. Note that Zone 1 relative humidity from LMDZiso is normalized to SST.

\begin{tabular}{|c|c|c|c|c|c|c|c|}
\hline & & \multicolumn{4}{|c|}{ IVI } & \multicolumn{2}{|c|}{ Zone 1} \\
\hline & & $d_{\mathrm{V}}$ obs & RH obs & $d_{\mathrm{v}}$ LMDZiso & RH LMDZiso & $d_{\mathrm{v}}$ LMDZiso & $\mathrm{RH}_{\mathrm{SST}}$ LMDZiso \\
\hline \multirow{4}{*}{ IVI } & $d_{\mathrm{V}}$ obs & - & -0.75 & 0.37 & -0.38 & 0.71 & -0.76 \\
\hline & RH obs & - & - & -0.15 & 0.20 & -0.53 & 0.69 \\
\hline & $d_{\mathrm{v}}$ LMDZiso & - & - & - & -0.55 & 0.39 & -0.28 \\
\hline & RH LMDZiso & - & - & - & - & -0.11 & 0.20 \\
\hline \multirow{2}{*}{ Zone 1} & $d_{\mathrm{V}}$ LMDZiso & - & - & - & - & - & -0.84 \\
\hline & RH LMDZiso & - & - & - & - & - & - \\
\hline
\end{tabular}

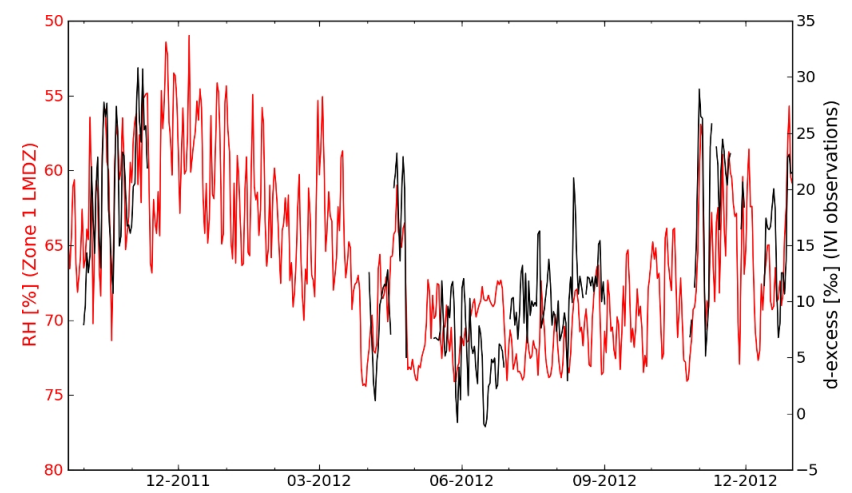

Fig. 13. Red: relative humidity (normalized to SST) (\%) averaged over Atlantic region from $49.4366^{\circ} \mathrm{N}, 41.25^{\circ} \mathrm{W}$ to $59.5775^{\circ} \mathrm{N}$, $22.5^{\circ} \mathrm{W}$, extracted from LMDZiso simulations, from September 2011 to December 2012. Black: $d_{\mathrm{v}}(\% o$ ) observed at Ivittuut station on the same period. Note that LMDZiso relative humidity is very similar to that from ECMWF analyses.

variance can be explained by the variability of Zone 1 relative humidity.

Altogether, we know (i) that the strong correlation between observed $d_{\mathrm{v}}$ and the relative humidity of Zone 1 suggests a key role for this source area; (ii) there are significant changes in moisture sources for Ivittuut, both at synoptic and seasonal scales (Figs. 7 and 8); (iii) despite biases of LMDZiso for $d_{\mathrm{v}}$, the spatial distribution of simulated $d_{\mathrm{v}}$ (see $d_{\mathrm{V}}$ maps issued from LMDZiso outputs in Supplement Fig. B.2) suggests that Arctic moisture is characterized by very high $d_{\mathrm{v}}$ in autumn; (iv) changes in the fraction of North Atlantic vs. Arctic moisture therefore contribute to the full magnitude of $d_{\mathrm{v}}$ variability at Ivittuut. If LMDZiso does not resolve these source changes properly, $d_{\mathrm{v}}$ variations could be underestimated. The effect of horizontal mixing between different sources might also play an important role in the final Ivittuut $d_{\mathrm{v}}$ signal. A misrepresentation of horizontal mixing could be linked with the model resolution, as highlighted by Werner et al. (2011) for Antarctica. In our case, small-scale storms channelled along the South Greenland coast are not resolved at the model resolution.
Our analysis confirms other studies suggesting that AGCMs fail to reproduce the magnitude of synoptic and seasonal $d_{\mathrm{v}}$ variations in Greenland (Steen-Larsen et al., 2013; Sjolte et al., 2011; Werner et al., 2011), and calls for a careful use of such model results for the quantitative interpretation of ice core records.

\section{Conclusions}

We have reported here a year-round monitoring of water vapour isotopic composition conducted in semi-autonomous conditions in southern Greenland, with only annual maintenance. After a first adjustment phase where data acquisition was interrupted by a storm and problems with the calibration system, the system has been fully operational. The accuracy of the validated data $\left(0.3 \%\right.$ for $\delta^{18} \mathrm{O}, 2.2 \%$ for $\delta \mathrm{D}$ and $2.3 \%$ ofor $d$ ) is sufficient to resolve diurnal, synoptic and seasonal variations in $\delta^{18} \mathrm{O}_{\mathrm{v}}$ and $d_{\mathrm{v}}$. The small diurnal cycle suggests limited effects of local processes (such as evapotranspiration, boundary layer dynamics) and the comparisons between our data, back-trajectory calculations and LMDZiso simulations confirm that the surface vapour isotopic composition is reflecting changes in large-scale moisture advection.

For $\delta^{18} \mathrm{O}_{\mathrm{v}}$, our data show that its variability is strongly driven by changes in local air temperature and humidity, as expected from Rayleigh distillation. However, we observe relatively small $\delta^{18} \mathrm{O}_{\mathrm{v}}-T$ slope $\left(0.37 \%{ }^{\circ} \mathrm{C}^{-1}\right)$ and changing relationships through seasons, likely due to seasonal shifts of moisture sources. Temperature variations only explain at best (in autumn) half of the $\delta^{18} \mathrm{O}_{\mathrm{v}}$ variance. We report specifically a divergence between $\delta^{18} \mathrm{O}_{\mathrm{v}}$ and temperature during the summer 2012 heat wave, associated with long-distance transport from an exceptional atmospheric river. The comparison between the isotopic measurements at Ivittuut with those acquired above the ice sheet (e.g. NEEM, Steen-Larsen et al., 2013) will offer an isotopic benchmark to test the parameterizations of atmospheric models for this event.

Based on vapour measurements and vapour calculated at equilibrium from precipitation isotopic composition measurements, we identify a difference in the seasonal cycle 
of $\delta^{18} \mathrm{O}_{\mathrm{v}}$ (in phase with local temperature) and $d_{\mathrm{v}}$. Beyond an anti-phase with $\delta^{18} \mathrm{O}_{\mathrm{v}}$ at the synoptic scale, $d_{\mathrm{v}}$ is minimum in spring and maximum in autumn. Variations of $d_{\mathrm{v}}$ appear strongly correlated at the synoptic and seasonal scale with relative humidity at the surface of a North Atlantic area, south of Iceland. Calculated from FLEXPART, moisture sources are identified in the Labrador Sea, the subtropical Atlantic and the North Atlantic. Shifts in evaporation conditions probably explain the variance of $\delta^{18} \mathrm{O}_{\mathrm{v}}$ which is not linearly related to Ivittuut meteorological data (temperature and humidity), and deviations from slopes expected from pure Rayleigh distillations.

The response function of the measurements against humidity suggests effects due to the use of DRIERITE in our calibration introduction system, for low humidity levels. While this does not impact the results reported here, further studies would benefit from an alternative calibration method using e.g. dry air cylinders.

Testing the robustness of our findings (such as the $d_{\mathrm{v}}$ peak in autumn) over longer time periods motivates an extension of the surface water vapour monitoring in Ivittuut over several years. This would make it possible to investigate the local fingerprint of changes in weather regimes and explore inter-annual variations.

The mismatch between LMDZiso simulated $d_{\mathrm{v}}$ and our data should be further investigated. The fact that LMDZiso simulates too small $d_{\mathrm{v}}$ variations at Ivittuut could be linked either to an underestimation of the variability of $d_{\mathrm{v}}$ at the moisture source and/or to an inadequate representation of the moisture sources mixing. A first test could be to run simulations at higher resolution, in order to explore how changes in model resolution would impact moisture transportation, as small-scale storms are known to transport moisture from the North Atlantic, below Iceland, towards South Greenland. A second test would be to investigate the isotopic signal associated with different moisture sources, using water tagging diagnostics (Risi et al., 2010b). This model-data comparison would benefit from similar comparisons with water vapour measurements from other locations along North Atlantic/Arctic air mass trajectories, especially in locations close to moisture sources, such as Bermuda (Steen-Larsen et al., 2014b).

\section{Supplementary material related to this article is available online at http://www.atmos-chem-phys.net/14/ 4419/2014/acp-14-4419-2014-supplement.zip.}

Acknowledgements. Thanks to partnerships established with local authorities (Kommuneqarfik Sermersooq) and the Danish navy (Grønland Kommando, GLK), the atmospheric observatory has been installed with logistical support from both sides. Precious logistic help has been provided to the station by Grønland Kommando since 2007. We want to thank them greatly for this very fruitful collaboration. We also acknowledge Sonia Falourd and
Bénédicte Minster for the isotopic measurements of precipitation samples. We finally warmly acknowledge the helpful comments and suggestions of Amaelle Landais, Guillaume Tremoy and Françoise Vimeux. LMDZ simulations were performed on the NEC supercomputer of the IDRIS computing centre. This research was funded by the ANR CEPS Green Greenland project (grant number ANR-10-CEPL-0008). Ivittuut station is funded by IPEV, CARBOOCEAN, ICOS.

Edited by: M. Heimann

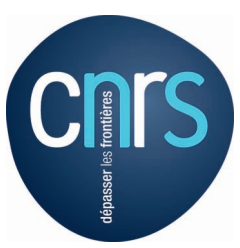

The publication of this article is financed by CNRS-INSU.

\section{References}

Aemisegger, F., Sturm, P., Graf, P., Sodemann, H., Pfahl, S., Knohl, A., and Wernli, H.: Measuring variations of $\delta^{18} \mathrm{O}$ and $\delta^{2} \mathrm{H}$ in atmospheric water vapour using two commercial laser-based spectrometers: an instrument characterisation study, Atmos. Meas. Tech., 5, 1491-1511, doi:10.5194/amt-5-1491-2012, 2012.

Benetti, M., Reverdin, G., Pierre, C., Merlivat, L., Risi, C., SteenLarsen, H. C. and Vimeux, F.: Deuterium excess in marine water vapor: dependency on relative humidity and surface wind speed during evaporation, J. Geophys. Res.-Atmos., 119, 584593, doi:10.1002/2013JD020535, 2014.

Bennartz, R., Shupe, M. D., Turner, D. D., Walden, V. P., Steffen, K., Cox, C. J., Kulie, M. S., Miller, N. B., and Pettersen, C.: July 2012 Greenland melt extent enhanced by low-level liquid clouds, Nature, 496, 83-86, doi:10.1038/nature12002, 2013.

Casado, M., Ortega, P., Masson-Delmotte, V., Risi, C., Swingedouw, D., Daux, V., Genty, D., Maignan, F., Solomina, O., Vinther, B., Viovy, N., and Yiou, P.: Impact of precipitation intermittency on NAO-temperature signals in proxy records, Clim. Past, 9, 871-886, doi:10.5194/cp-9-871-2013, 2013.

Craig, H. and Gordon, L. I.: Isotopic oceanography, Deuterium and oxygen 18 variations in the ocean and marine atmosphere Proceedings Third Spoleto Nuclear Geology Conference C.N.D.R, Pisa, 9-130, 1966.

Cuffey, K. M., Alley, R. B., Grootes, P. M., and Anandakrishnan, S.: Toward using borehole temperatures to calibrate an isotopic paleothermometer in central Greenland, Global Planet. Change, 6, 265-268, doi:10.1016/0921-8181(92)90042-9, 1992.

Dahl-Jensen, D., Mosegaard, K., Gundestrup, N., Clow, G. D., Johnsen, S. J., Hansen, A. W., and Balling, N.: Past temperatures directly from the Greenland ice sheet, Science, 282, 268-271, doi:10.1126/science.282.5387.268, 1998.

Dansgaard, W.: Stable isotopes in precipitation, Tellus, 16, 436468, doi:10.1111/j.2153-3490.1964.tb00181.x, 1964.

Fettweis, X., Hanna, E., Lang, C., Belleflamme, A., Erpicum, M., and Gallée, H.: Brief communication "Important role of the midtropospheric atmospheric circulation in the recent surface melt increase over the Greenland ice sheet”, The Cryosphere, 7, 241 248, doi:10.5194/tc-7-241-2013, 2013. 
Gribanov, K., Jouzel, J., Bastrikov, V., Bonne, J.-L., Breon, F.M., Butzin, M., Cattani, O., Masson-Delmotte, V., Rokotyan, N., Werner, M., and Zakharov, V.: ECHAM5-wiso water vapour isotopologues simulation and its comparison with WS-CRDS measurements and retrievals from GOSAT and ground-based FTIR spectra in the atmosphere of Western Siberia, Atmos. Chem. Phys. Discuss., 13, 2599-2640, doi:10.5194/acpd-132599-2013, 2013.

Guillevic, M., Bazin, L., Landais, A., Kindler, P., Orsi, A., MassonDelmotte, V., Blunier, T., Buchardt, S. L., Capron, E., Leuenberger, M., Martinerie, P., Prié, F., and Vinther, B. M.: Spatial gradients of temperature, accumulation and $\delta^{18} \mathrm{O}$-ice in Greenland over a series of Dansgaard-Oeschger events, Clim. Past, 9, 1029-1051, doi:10.5194/cp-9-1029-2013, 2013.

Hoffmann, G., Stievenard, M., Jouzel, J., White, J., and Johnsen, S.: Deuterium excess record from central Greenland: modeling and observations, in: International Symposium on Isotopes Techniques in the Study of Past and Current Environmental changes in the Hydrosphere and the Atmosphere, 14-18 April 1997, IAEA, Vienna, 591-602, 1998.

Hourdin, F., Musat, I., Bony, S., Braconnot, P., Codron, F., Dufresne, J.-L., Fairhead, L., Filiberti, M.-A., Friedlingstein, P., Grandpeix, J.-Y., Krinner, G., LeVan, P., Li, Z.-X., and Lott, F.: The LMDZ4 general circulation model: climate performance and sensitivity to parametrized physics with emphasis on tropical convection, Clim. Dynam., 27, 787-813, doi:10.1007/s00382006-0158-0, 2006.

Jacob, H. and Sonntag, C.: An 8-year record of the seasonal variation of ${ }^{2} \mathrm{H}$ and ${ }^{18} \mathrm{O}$ in atmospheric water vapour and precipitation at Heidelberg, Germany, Tellus B, 43, 291-300, doi:10.1034/j.1600-0889.1991.t01-2-00003.x, 1991.

Johnsen, S. J.: Stable isotope homogenization of polar firn and ice, in: Isotopes and Impurities in Snow and Ice, IAHS-AISH Publ. 118, I.U.G.G. XVI, General Assembly, Grenoble August/September 1975, Washington, D.C., 210-219, 1977.

Johnsen, S. J., Clausen, H. B., Dansgaard, W., Fuhrer, K., Gundestrup, N., Hammer, C. U., Iversen, P., Jouzel, J., Stauffer, B., and Steffensen, J. P.: Irregular glacial interstadials recorded in a new Greenland ice core, Nature, 359, 311-313, 1992.

Johnsen, S. J., Clausen, H. B., Cuffey, K. M., Hoffmann, G., Schwander, J., and Creyts, T.: Diffusion of stable isotopes in polar firn and ice: the isotope effect in firn diffusion, Phys. Ice Core Rec., 159, 121-140, 2000.

Jouzel, J.: Water stable isotopes: atmospheric composition and applications in polar ice core studies, Treat. Geochem., 4, 213-243, doi:10.1016/B0-08-043751-6/04040-8, 2003.

Jouzel, J., Stiévenard, M., Johnsen, S., Landais, A., MassonDelmotte, V., Sveinbjornsdottir, A., Vimeux, F., von Grafenstein, U., and White, J.: The GRIP deuterium-excess record, Quaternary Sci. Rev., 26, 1-17, doi:10.1016/j.quascirev.2006.07.015, 2007.

Jouzel, J., Delaygue, G., Landais, A., Masson-Delmotte, V., Risi, C., and Vimeux, F.: Water isotopes as tools to document oceanic sources of precipitation, Water Resour. Res., 49, 74697486, doi:10.1002/2013WR013508, 2013.

Kindler, P., Guillevic, M., Baumgartner, M., Schwander, J., Landais, A., and Leuenberger, M.: NGRIP temperature reconstruction from 10 to $120 \mathrm{kyrb2k}$, Clim. Past Discuss., 9, 4099-4143, doi:10.5194/cpd-9-4099-2013, 2013.
Krinner, G. and Werner, M.: Impact of precipitation seasonality changes on isotopic signals in polar ice cores: a multi-model analysis, Earth Planet. Sc. Lett., 216, 525-538, doi:10.1016/S0012-821X(03)00550-8, 2003.

Krinner, G., Genthon, C., and Jouzel, J.: GCM analysis of local influences on ice core delta signals, Geophys. Res. Lett., 24, 2825 2828, doi:10.1029/97GL52891, 1997.

Kurita, N.: Origin of Arctic water vapor during the ice-growth season, Geophys. Res. Lett., 38, L02709, doi:10.1029/2010GL046064, 2011.

Lee, X., Smith, R., and Williams, J.: Water vapour ${ }^{18} \mathrm{O} /{ }^{16} \mathrm{O}$ isotope ratio in surface air in New England, USA, Tellus B, 58, 293-304, doi:10.1111/j.1600-0889.2006.00191.x, 2006.

Liu, Y., Key, J. R., Ackerman, S. A., Mace, G. G., and Zhang, Q.: Arctic cloud macrophysical characteristics from CloudSat and CALIPSO, Remote Sens. Environ., 124, 159-173, doi:10.1016/j.rse.2012.05.006, 2012.

Majoube, M.: Fractionnement en oxygène 18 et en deutérium entre l'eau et sa vapeur, J. Chim. Phys., 68, 1423-1436, 1971a.

Majoube, M.: Fractionnement en oxygène 18 entre la glace et la vapeur d'eau, J. Chem. Phys., 68, 625-636, 1971b.

Masson-Delmotte, V., Jouzel, J., Landais, A., Stievenard, M., Johnsen, S. J., White, J. W. C., Werner, M., Sveinbjornsdottir, A., and Fuhrer, K.: GRIP Deuterium excess reveals rapid and orbitalscale changes in Greenland moisture origin, Science, 309, 118 121, doi:10.1126/science.1108575, 2005.

Masson-Delmotte, V., Braconnot, P., Hoffmann, G., Jouzel, J., Kageyama, M., Landais, A., Lejeune, Q., Risi, C., Sime, L., Sjolte, J., Swingedouw, D., and Vinther, B.: Sensitivity of interglacial Greenland temperature and $\delta^{18} \mathrm{O}$ : ice core data, orbital and increased $\mathrm{CO}_{2}$ climate simulations, Clim. Past, 7, 10411059, doi:10.5194/cp-7-1041-2011, 2011.

Merlivat, L. and Jouzel, J.: Global climatic interpretation of the deuterium-oxygen 18 relationship for precipitation, J. Geophys. Res.-Oceans, 84, 5029-5033, doi:10.1029/JC084iC08p05029, 1979.

Merlivat, L. and Nief, G.: Fractionnement isotopique lors des changements d'état solide-vapeur et liquide-vapeur de l'eau à des températures inférieures à $0^{\circ} \mathrm{C}$, Tellus, 19, 122-127, doi:10.1111/j.2153-3490.1967.tb01465.x, 1967.

Midhun, M., Lekshmy, P. R., and Ramesh, R.: Hydrogen and oxygen isotopic compositions of water vapor over the Bay of Bengal during monsoon, Geophys. Res. Lett., 40, 6324-6328, doi:10.1002/2013GL058181, 2013.

NEEM Community Members: Eemian interglacial reconstructed from a Greenland folded ice core, Nature, 493, 489-494, doi:10.1038/nature11789, 2013.

Neff, W., Compo, G., Martin Ralph, F., and Shupe, M.: Continental heat anomalies and the extreme melting of the Greenland ice surface in 2012 and 1889, J. Geophys. Res.-Atmos., submitted, 2013.

Nghiem, S. V., Hall, D. K., Mote, T. L., Tedesco, M., Albert, M. R., Keegan, K., Shuman, C. A., DiGirolamo, N. E., and Neumann, G.: The extreme melt across the Greenland ice sheet in 2012, Geophys. Res. Lett., 39, L20502, doi:10.1029/2012GL053611, 2012 
Ortega, P., Swingedouw, D., Masson-Delmotte, V., Risi, C., Vinther, B., Vautard, R., and Yoshimura, K.: Characterizing atmospheric circulation signals in Greenland ice cores: insights from the weather regime approach, Clim. Dynam., doi:10.1007/s00382-014-2074-z, in press, 2014.

Persson, A., Langen, P. L., Ditlevsen, P., and Vinther, B. M.: The influence of precipitation weighting on interannual variability of stable water isotopes in Greenland, J. Geophys. Res.-Atmos., 116, D20120, doi:10.1029/2010JD015517, 2011.

Pfahl, S. and Sodemann, H.: What controls deuterium excess in global precipitation?, Clim. Past Discuss., 9, 4745-4770, doi:10.5194/cpd-9-4745-2013, 2013.

Pfahl, S. and Wernli, H.: Air parcel trajectory analysis of stable isotopes in water vapor in the eastern Mediterranean, J. Geophys. Res.-Atmos., 113, D20104, doi:10.1029/2008JD009839, 2008.

Risi, C., Bony, S., and Vimeux, F.: Influence of convective processes on the isotopic composition $\left(\delta^{18} \mathrm{O}\right.$ and $\left.\delta \mathrm{D}\right)$ of precipitation and water vapor in the tropics: 2. Physical interpretation of the amount effect, J. Geophys. Res.-Atmos., 113, D19306, doi:10.1029/2008JD009943, 2008.

Risi, C., Bony, S., Vimeux, F., and Jouzel, J.: Water-stable isotopes in the LMDZ4 general circulation model: model evaluation for present-day and past climates and applications to climatic interpretations of tropical isotopic records, J. Geophys. Res.-Atmos., 115, D12118, doi:10.1029/2009JD013255, 2010a.

Risi, C., Landais, A., Bony, S., Jouzel, J., Masson-Delmotte, V., and Vimeux, F.: Understanding the o-17 excess glacial-interglacial variations in Vostok precipitation, J. Geophys. Res.-Atmos., 115, D10112, doi:10.1029/2008JD011535, 2010b.

Rousseau, D.-D., Duzer, D., Cambon, G., Jolly, D., Poulsen, U., Ferrier, J., Schevin, P., and Gros, R.: Long distance transport of pollen to Greenland, Geophys. Res. Lett., 30, 1765, doi:10.1029/2003GL017539, 2003.

Rozanski, K., Araguás-Araguás, L., and Gonfiantini, R.: Isotopic patterns in modern global precipitation, in: Geophraphical Monograph Series, edited by: Swart, P. K., Lohmann, K. C., McKenzie, J., and Savin, S., vol. 78, American Geophysical Union, Washington, D.C., 1-36, 1993.

Severinghaus, J. P. and Brook, E. J.: Abrupt climate change at the end of the Last Glacial Period inferred from trapped air in polar ice, Science, 286, 930-934, 10542141, doi:10.1126/science.286.5441.930, 1999.

Sime, L. C., Risi, C., Tindall, J. C., Sjolte, J., Wolff, E. W., Masson-Delmotte, V., and Capron, E.: Warm climate isotopic simulations: what do we learn about interglacial signals in Greenland ice cores?, Quaternary Sci. Rev., 67, 59-80, doi:10.1016/j.quascirev.2013.01.009, 2013.

Sjolte, J., Hoffmann, G., Johnsen, S. J., Vinther, B. M., MassonDelmotte, V., and Sturm, C.: Modeling the water isotopes in Greenland precipitation 1959-2001 with the meso-scale model REMO-iso, J. Geophys. Res.-Atmos., 116, D18105, doi:10.1029/2010JD015287, 2011.

Sodemann, H. and Stohl, A.: Asymmetries in the moisture origin of Antarctic precipitation, Geophys. Res. Lett., 36, L22803, doi:10.1029/2009GL040242, 2009.

Sodemann, H., Schwierz, C., and Wernli, H.: Interannual variability of Greenland winter precipitation sources: Lagrangian moisture diagnostic and North Atlantic Oscillation influence, J. Geophys. Res.-Atmos., 113, D12111, doi:10.1029/2007JD008503, 2008a.
Sodemann, H., Masson-Delmotte, V., Schwierz, C., Vinther, B. M., and Wernli, H.: Interannual variability of Greenland winter precipitation sources: 2. Effects of North Atlantic Oscillation variability on stable isotopes in precipitation, J. Geophys. Res., 113, D03107, doi:10.1029/2007JD009416, 2008b.

Steen-Larsen, H. C., Masson-Delmotte, V., Sjolte, J., Johnsen, S. J., Vinther, B. M., Bréon, F.-M., Clausen, H. B., Dahl-Jensen, D., Falourd, S., Fettweis, X., Gallée, H., Jouzel, J., Kageyama, M., Lerche, H., Minster, B., Picard, G., Punge, H. J., Risi, C., Salas, D., Schwander, J., Steffen, K., Sveinbjörnsdóttir, A. E., Svensson, A., and White, J.: Understanding the climatic signal in the water stable isotope records from the NEEM shallow firn/ice cores in northwest Greenland, J. Geophys. Res.-Atmos., 116, D06108, doi:10.1029/2010JD014311, 2011.

Steen-Larsen, H. C., Johnsen, S. J., Masson-Delmotte, V., Stenni, B., Risi, C., Sodemann, H., Balslev-Clausen, D., Blunier, T., Dahl-Jensen, D., Ellehøj, M. D., Falourd, S., Grindsted, A., Gkinis, V., Jouzel, J., Popp, T., Sheldon, S., Simonsen, S. B., Sjolte, J., Steffensen, J. P., Sperlich, P., Sveinbjörnsdóttir, A. E., Vinther, B. M., and White, J. W. C.: Continuous monitoring of summer surface water vapor isotopic composition above the Greenland Ice Sheet, Atmos. Chem. Phys., 13, 4815-4828, doi:10.5194/acp-13-4815-2013, 2013.

Steen-Larsen, H. C., Masson-Delmotte, V., Hirabayashi, M., Winkler, R., Satow, K., Prié, F., Bayou, N., Brun, E., Cuffey, K. M., Dahl-Jensen, D., Dumont, M., Guillevic, M., Kipfstuhl, S., Landais, A., Popp, T., Risi, C., Steffen, K., Stenni, B., and Sveinbjörnsdottír, A. E.: What controls the isotopic composition of Greenland surface snow?, Clim. Past, 10, 377-392, doi:10.5194/cp-10-377-2014, 2014a.

Steen-Larsen, H. C., Sveinbjörnsdottir, A. E., Peters, A. J., MassonDelmotte, V., Guishard, M. P., Hsiao, G., Jouzel, J., Noone, D., Warren, J. K., and White, J. W. C.: Climatic controls on water vapor deuterium excess in the marine boundary layer of the North Atlantic based on 500 days of in situ, continuous measurements, Atmos. Chem. Phys. Discuss., 14, 2363-2401, doi:10.5194/acpd-14-2363-2014, 2014b.

Steffensen, J. P., Andersen, K. K., Bigler, M., Clausen, H. B., Dahl-Jensen, D., Fischer, H., Goto-Azuma, K., Hansson, M., Johnsen, S. J., Jouzel, J., Masson-Delmotte, V., Popp, T., Rasmussen, S. O., Röthlisberger, R., Ruth, U., Stauffer, B., SiggaardAndersen, M.-L., Sveinbjörnsdóttir, A. E., Svensson, A., and White, J. W. C.: High-resolution Greenland ice core data show abrupt climate change happens in few years, Science, 321, 680 684, doi:10.1126/science.1157707, 2008.

Stephens, B. B., Keeling, R. F., Heimann, M., Six, K. D., Murnane, R., and Caldeira, K.: Testing global ocean carbon cycle models using measurements of atmospheric $\mathrm{O}_{2}$ and $\mathrm{CO}_{2}$ concentration, Global Biogeochem. Cy., 12, 213-230, doi:10.1029/97GB03500, 1998.

Stohl, A., Forster, C., Frank, A., Seibert, P., and Wotawa, G.: Technical note: The Lagrangian particle dispersion model FLEXPART version 6.2, Atmos. Chem. Phys., 5, 2461-2474, doi:10.5194/acp-5-2461-2005, 2005.

Thomas, E. R., Wolff, E. W., Mulvaney, R., Johnsen, S. J., Steffensen, J. P., and Arrowsmith, C.: Anatomy of a DansgaardOeschger warming transition: high-resolution analysis of the North Greenland Ice Core Project ice core, J. Geophys. Res.Atmos., 114, D08102, doi:10.1029/2008JD011215, 2009. 
Tremoy, G., Vimeux, F., Cattani, O., Mayaki, S., Souley, I., and Favreau, G.: Measurements of water vapor isotope ratios with wavelength-scanned cavity ring-down spectroscopy technology: new insights and important caveats for deuterium excess measurements in tropical areas in comparison with isotope-ratio mass spectrometry, Rapid Commun. Mass Spectr., 25, 3469-3480, doi:10.1002/rcm.5252, 2011.

Uemura, R., Matsui, Y., Yoshimura, K., Motoyama, H., and Yoshida, N.: Evidence of deuterium excess in water vapor as an indicator of ocean surface conditions, J. Geophys. Res.-Atmos., 113, D19114, doi:10.1029/2008JD010209, 2008.

Vinther, B., Jones, P., Briffa, K., Clausen, H., Andersen, K., DahlJensen, D., and Johnsen, S.: Climatic signals in multiple highly resolved stable isotope records from Greenland, Quaternary Sci. Rev., 29, 522-538, doi:10.1016/j.quascirev.2009.11.002, 2010.
Welp, L. R., Lee, X., Griffis, T. J., Wen, X.-F., Xiao, W., Li, S., Sun, X., Hu, Z., Martin, M. V., and Huang, J.: A metaanalysis of water vapor deuterium-excess in the midlatitude atmospheric surface layer, Global Biogeochem. Cy., 26, GB3021, doi:10.1029/2011GB004246, 2012.

Werner, M., Langebroek, P. M., Carlsen, T., Herold, M., and Lohmann, G.: Stable water isotopes in the ECHAM5 general circulation model: toward high-resolution isotope modeling on a global scale, J. Geophys. Res.-Atmos., 116, D15109, doi:10.1029/2011JD015681, 2011. 